\title{
Review
}

\section{CXCL13 in Cancer and Other Diseases: Biological Functions, Clinical Significance, and Therapeutic Opportunities}

\author{
San-Hui Gao ${ }^{1,2}$, Sheng-Zhi Liu ${ }^{3,4}$, Gui-Zhen Wang ${ }^{1,2}$ and Guang-Biao Zhou ${ }^{1,2, * \mathbb{D}}$ \\ 1 State Key Laboratory of Molecular Oncology, National Cancer Center/National Clinical Research Center for \\ Cancer/Cancer Hospital, Chinese Academy of Medical Sciences and Peking Union Medical College, \\ Beijing 100021, China; dlbe2011@foxmail.com (S.-H.G.); gzwang@cicams.ac.cn (G.-Z.W.) \\ 2 State Key Laboratory of Membrane Biology, Institute of Zoology, Chinese Academy of Sciences \& University \\ of Chinese Academy of Sciences, Beijing 100101, China \\ 3 Department of Pharmacology, School of Pharmaceutical Sciences, Capital Medical University, \\ Beijing 100069, China; szliu@ccmu.edu.cn or liu441@iupui.edu \\ 4 Department of Biomedical Engineering, Indiana University-Purdue University Indianapolis, \\ Indianapolis, IN 46202, USA \\ * Correspondence: gbzhou@cicams.ac.cn
}

Citation: Gao, S.-H.; Liu, S.-Z.; Wang, G.-Z; Zhou, G.-B. CXCL13 in Cancer and Other Diseases: Biological

Functions, Clinical Significance, and Therapeutic Opportunities. Life 2021, 11, 1282. https://doi.org/10.3390/ life11121282

Academic Editors: Hung-Chi Cheng and Payaningal R. Somanath

Received: 4 August 2021

Accepted: 12 November 2021

Published: 23 November 2021

Publisher's Note: MDPI stays neutral with regard to jurisdictional claims in published maps and institutional affiliations.

Copyright: (c) 2021 by the authors. Licensee MDPI, Basel, Switzerland. This article is an open access article distributed under the terms and conditions of the Creative Commons Attribution (CC BY) license (https:// creativecommons.org/licenses/by/ $4.0 /)$.

\begin{abstract}
The development of cancer is a multistep and complex process involving interactions between tumor cells and the tumor microenvironment (TME). C-X-C chemokine ligand 13 (CXCL13) and its receptor, CXCR5, make crucial contributions to this process by triggering intracellular signaling cascades in malignant cells and modulating the sophisticated TME in an autocrine or paracrine fashion. The CXCL13/CXCR5 axis has a dominant role in B cell recruitment and tertiary lymphoid structure formation, which activate immune responses against some tumors. In most cancer types, the CXCL13/CXCR5 axis mediates pro-neoplastic immune reactions by recruiting suppressive immune cells into tumor tissues. Tobacco smoke and haze (smohaze) and the carcinogen benzo(a)pyrene induce the secretion of CXCL13 by lung epithelial cells, which contributes to environmental lung carcinogenesis. Interestingly, the knockout of CXCL13 inhibits benzo(a)pyrene-induced lung cancer and azoxymethane/dextran sodium sulfate-induced colorectal cancer in mice. Thus, a better understanding of the context-dependent functions of the CXCL13/CXCR5 axis in tumor tissue and the TME is required to design an efficient immune-based therapy. In this review, we summarize the molecular events and TME alterations caused by CXCL13/CXCR5 and briefly discuss the potentials of agents targeting this axis in different malignant tumors.
\end{abstract}

Keywords: C-X-C chemokine ligand 13 (CXCL13); C-X-C chemokine receptor type 5 (CXCR5); cancer; tumor microenvironment

\section{Introduction}

Chemokines are a family of chemotactic cytokines with small molecular weights (8-14 kDa) [1]. Chemokines are classified into four groups according to the position of the first two cysteines closest to the amino terminus: C, CC, CXC, and CX3C [2]. Chemokines exert their functions by binding to their receptors, which are seven-transmembrane guanineprotein-coupled receptors (GPCRs) [3]. Chemokines have important roles in regulating lymphoid tissue development, immune homeostasis, and inflammatory responses by directing the migration of leukocytes into the injured or infected tissues [2]. A complex chemokine-chemokine receptor signaling network is critical to the tumor microenvironment (TME), which makes pivotal contributions to tumor cell proliferation, migration, invasion, angiogenesis, and evasion of anti-tumor immunity, facilitating tumor initiation, progression, and metastasis [4-8].

Chemokines and their receptors also modulate lymphocyte populations in the TME, thus inducing resistance to immune checkpoint inhibitors that exhibit remarkable efficacies 
on a proportion of patients with many cancer types $[9,10]$. Inconsistent with these observations, targeting chemokine receptors with neutralizing antibodies endow a more sensitized phenotype and enhance responses to immune checkpoint blockades [11,12].

\section{CXCL13/CXCR5 and Immune Homeostasis}

\subsection{CXCL13/CXCR5: Genes and Proteins}

C-X-C chemokine ligand 13 (CXCL13), also known as B-cell attracting chemokine 1 (BCA-1) or B-lymphocyte chemoattractant (BLC), was originally identified as a homeostatic chemokine to attract B cells, a minority of T cells, and macrophages [13]. The human CXCL13 gene localizes on chromosome 4q21 and encodes CXCL13 protein, which has 109 amino acids, a molecular mass of $12,664 \mathrm{Da}$, and a crystal structure as below (Figure 1A). The receptor of CXCL13 is the C-X-C chemokine receptor type 5 (CXCR5), which is also named Burkitt's lymphoma receptor 1 (BLR1) and is defined as a member of the superfamily of seven-transmembrane GPCRs (Figure 1B). CXCR5 has two transcripts, both localized on the cell membrane [14], and is expressed by follicular helper T cells (Tfh) [15], circulating $\mathrm{CD}^{+} \mathrm{T}$ cells [16], B cells [17], CD68 ${ }^{+}$macrophages [18], and tumor cells. Moreover, FANCAmediated CXCR5 neddylation is involved in targeting the receptor to the cell membrane, and CXCR5 neddylation stimulates cell migration and motility [19].

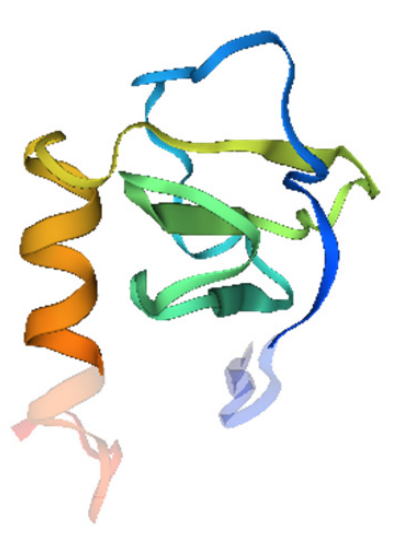

(A)

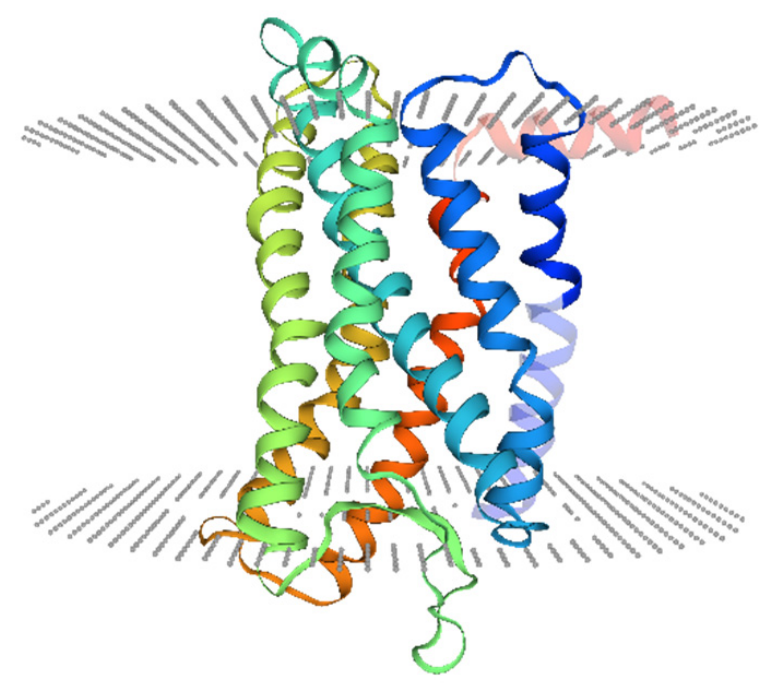

(B)

Figure 1. Crystal structure of CXCL13 and CXCR5. (A). Illustration of the CXCL13 monomer (UniProKB-O43927) showing domain hits with deep coloration. (B). Illustration of the CXCR5 monomer (UniProKB-P32302) showing seven transmembrane helixes and domain hits (deeply colored). Structural models were obtained from SWISS-MODEL (http:/ / swissmodel.expasy.org/ repository/. accessed on 15 April 2021).

\subsection{CXCL13/CXCR5 Axis}

The precise mechanism of how the CXCR5 receptor responds to CXCL13 and mediates signaling activation has not been fully elucidated. Evidence has demonstrated that CXCR5 interacts with cytosolic and membrane proteins to form heterodimers and heterotrimers, respectively [20-22]. CXCR5 couples to cytosolic $\alpha, \beta$, and $\gamma$ subunits of $G$ proteins to form heterotrimeric guanine nucleotide-binding proteins [20]. After CXCL13 binds to CXCR5, $G$ proteins dissociate from CXCR5, dividing into $G_{\alpha}$ and $G_{\beta \gamma}$, which stimulate different downstream molecules and subsequently trigger specific intracellular signal transduction pathways $[20,23]$. The intracellular domains, and probably the transmembrane-spanning domains of CXCR5, are required to activate $G$ proteins [24,25]. CXCR5 can also form heterodimers with membrane proteins, such as CXCR4 and Epstein-Barr virus-induced 
receptor 2 (EBI2) [20,22]. The EBI2/CXCR5 heterodimer lowers the affinity of CXCL13 for CXCR5 and reduces the activation of $\mathrm{G}$ proteins, potentially contributing to the alteration of the CXCR5 binding pocket by heterodimer formation [22].

\subsection{Physiological Functions of CXCL13/CXCR5}

CXCL13 is abundantly expressed on follicular helper T cells (Tfh), follicular dendritic cells (FDCs), and stromal cells in the follicles of secondary lymphoid organs (SLOs) and is essential for the development of the B cell zones of SLOs [13,26-28]. SLOs, which include the spleen, lymph nodes, and Peyer's patches, coordinate antigen-specific primary immune responses via promoting the interactions between antigen-presenting cells and lymphocytes. CXCR5 is expressed by mature B lymphocytes [29], a subpopulation of follicular B helper T cells [30,31], and antigen-bearing dendritic cells (DCs) [32], which control their migration into SLOs towards the gradient of CXCL13 [26,33-35]. CXCR5 regulates Burkitt's lymphoma (BL) lymphomagenesis, B cell differentiation, and migration $[25,29,34]$.

CXCL13 and CXCR5 are required to maintain SLO architecture $[26,34,36]$, whereas deficiencies in CXCL13 [26] and CXCR5 [34] result in the abnormal development of lymph nodes and Peyer's patches. Consistently blocking the CXCL13/CXCR5 axis inhibits the migration and localization of $\mathrm{B}$ cells to lymphoid follicles, which are also called $\mathrm{B}$ cell zones in SLOs $[13,26,27,34]$. CXCL13/CXCR5 signaling enhances B cell receptor (BCR)-triggered B cell activation by shaping cell dynamics [37]. Proline-rich tyrosine kinase (Pyk2) and focal adhesion kinase (FAK) are required for CXCL13-induced chemotaxis of B-2 cells into the lymph follicles and B cells in the marginal zone (MZ), since both the Pyk2 inhibitor and FAK inhibitor suppress CXCL13-induced migration of B-2 cells and MZ B cells (B cells in marginal zone) [38].

In response to CXCL13 secreted by Tfh, FDCs, or marginal reticular cells (MRC), and peripheral CXCR5 ${ }^{+} \mathrm{B}$ cells are recruited into the lymphoid follicles or germinal center (GC) in the SLOs through high endothelial venules (HEVs) (Figure 2). In the lymphoid follicles, a positive feedback loop mediated by CXCL13 boosts follicle development and sustains SLOs homeostasis. On one hand, CXCL13 secreted by FDCs upregulates membrane lymphotoxin $\alpha 1 \beta 2$ (LT $\alpha \beta)$ on B cells. On the other hand, LT $\alpha \beta$ interacts with the lymphotoxin- $\beta$ receptor (LT $\beta R$ ) on FDCs and triggers FDC development, mutation, and CXCL13 production (Figure 2). In GCs, the expression of LT $\alpha \beta$ on B cells is independent of CXCL13 [26]. In the GCs of Peyer's patches, the formyl peptide receptor (FPR) expressed on FDCs interacts with its endogenous ligands LL-37, promoting the generation of CXCL13 and B cell activators, and subsequently activates B cells [39]. LL-37-mediated FPR-2 signaling in follicular dendritic cells contributes to B cell activation. The CXCL13/CXCR5 axis also connects Tfh cells with B cells. These CXCR5-expressing Tfh cells migrate to the lymphoid follicles under the chemotaxis of CXCL13, where they subsequently initiate GC formation, BCR affinity maturation, and B cell differentiation into antibody-producing plasma cells and memory cells by providing costimulatory receptors and cytokines (Figure 2) [40-42]. Although most B cells in SLOs are B-2 cells, CXCL13 also recruits B-1 cells into the body cavity, which triggers early immune defense by producing the low-affinity antibody IgM [43,44]. Overall, the CXCL13/CXCR5 axis is essential for SLO structure and immunity responses. 


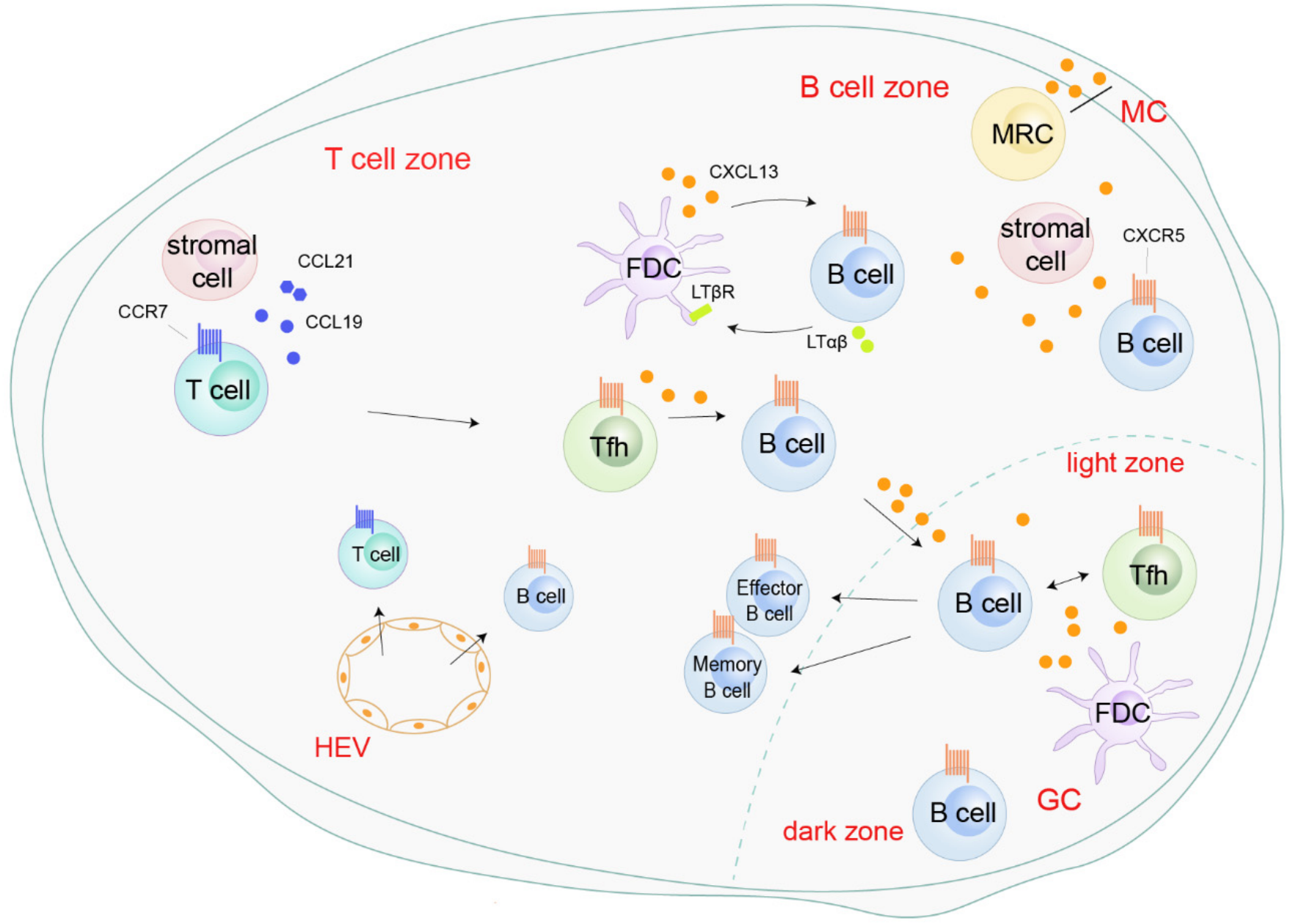

Figure 2. Roles of the CXCL13/CXCR5 axis in secondary lymphoid organs. CXCL13, secreted by follicular helper T cells (Tfh), follicular dendritic cells (FDCs), and marginal reticular cells (MRC), recruits peripheral CXCR5 ${ }^{+}$B cells into the B cell zone or germinal center (GC) through high endothelial venules (HEVs). In the B cell zone, CXCL13 enhances follicle development and sustains secondary lymphoid organ homeostasis by a positive-feedback loop with B cells and FDC [26]. CXCR5 ${ }^{+}$Tfh migrate into B cell zones, initiating GC formation and B cell receptor (BCR) affinity maturation and promoting the differentiation of B cells into antibody-producing plasma cells and memory cells [40-42].

\section{CXCL13/CXCR5 and Non-Cancerous Diseases}

CXCL13 signaling is involved in multiple diseases and exhibits context-dependent effects in inflammatory conditions and tumor tissues. Generally, the tertiary lymphoid structure (TLS) will develop in non-lymphoid tissues within or near the pathological sites when an organism suffers from disorders, including persistent infection, autoimmune disease, chronic obstructive pulmonary disease (COPD), and cancer (Figure 3) [45,46]. Structurally, TLSs have B cell zones, T cell zones, GCs, and HEVs. 


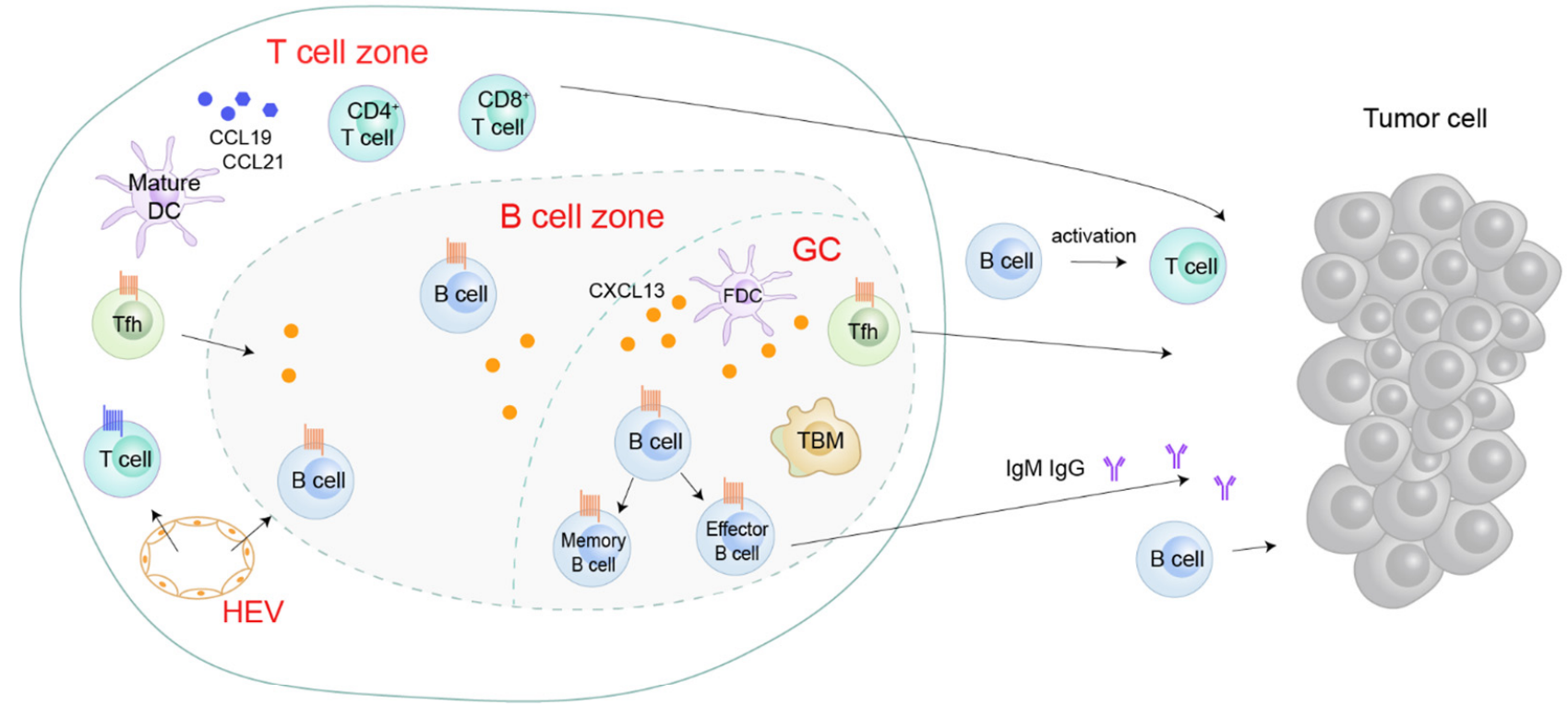

Figure 3. Roles of the CXCL13/CXCR5 axis in the tertiary lymphoid structure (TLS). CXCL13 is aberrantly expressed in the TLS. CXCL13 attracts CXCR5 ${ }^{+}$Tfh and B cells to the B cell zone or GC, potentiating B cell maturation and TLS formation [47,48]. In TLS, B cells' secret immunoglobulins activate T cells or directly target cancer cells [15,49]. Tfh, follicular helper T cells; FDC, follicular dendritic cells; GC, germinal center; HEV, high endothelial venules; TBM, tingible body macrophages.

CXCL13 is aberrantly expressed and acts as the main orchestrator in TLSs $[24,45,47,50-54]$. After viral infection, type I interferon is produced and can induce CXCL13 production in a population of lung fibroblasts, driving CXCR5-dependent recruitment of $B$ cells and initiating ectopic germinal center formation [55]. Primary pulmonary fibroblast-secreted CXCL13 induces the formation of inducible bronchus-associated lymphoid tissue (iBALT), which drives immune responses to fungal stimulation within the lungs [47]. In one fatal and irreversible interstitial lung disease, idiopathic pulmonary fibrosis, CXCL13 is produced by CD68- and CD206-positive alveolar macrophages, and the serum CXCL13 concentration predicts the progression and severity of the disease [56]. In the lungs of mice and patients bearing COPD induced by chronic cigarette smoke exposure, CXCL13 is elevated in the lymphoid follicles and mediates the formation of TLS, resulting in chronic inflammation in bronchoalveolar lavage and destruction of alveolar walls [45].

In the synovial tissues of rheumatoid arthritis, CXCL13 is produced by PD$1^{\text {hi }}{ }^{2 X C R 5}{ }^{-} \mathrm{CD}^{+} \mathrm{T}$ cells [57]. CXCL13 is also a key regulator of B cell recruitment to the cerebrospinal fluid in acute Lyme neuroborreliosis [58]. CXCL13 participates in TLS formation in some autoimmune diseases, such as primary Sjögren's syndrome [59,60], systemic lupus erythematosus, myasthenia gravis [61], and atherosclerosis [62], but not in rheumatoid arthritis [63] or acute Lyme neuroborreliosis [64]. CXCL13 is also highly produced during adipogenesis, and has been shown to be a differentiation- and hypoxiainduced adipocytokine that exacerbates the inflammatory phenotype of adipocytes through the induction of the pleckstrin homology $(\mathrm{PH})$ domain leucine-rich repeat protein Ser/Thr specific phosphatase family 1 (PHLPP1), which regulates AKT activation [65,66].

CXCL13 is upregulated by Helicobacter suis, the most prevalent non-Helicobacter pylori species colonizing the stomach of humans suffering from gastric disease [67]. CXCL13 is also induced in Helicobacter-related chronic gastritis and is involved in the formation of lymphoid follicles and the gastric lymphomas of mucosa-associated lymphoid tissue types $[68,69]$. In non-alcoholic fatty liver disease (NAFLD), repressed expression of CXCL13 may ameliorate steatosis-related inflammation [70]. CXCL13 drives spinal astrocyte activation and neuropathic pain via CXCR5 [71], and is critical to preserve motor neurons in 
amyotrophic lateral sclerosis [72]. Further understanding of the regulations and functions of the CXCL13/CXCR5 axis will aid the rational design of therapeutics for these diseases.

\section{CXCL13/CXCR5 and Cancer}

The CXCL13/CXCR5 axis is involved in the regulation of cancer cell survival, apoptosis, proliferation, differentiation, migration, invasion, and adaptive immunity, and shows dichotomic anti- and pro-tumor functions in the TME [21,50,73-78] (Figure 4). CXCL13 and CXCR5 have important roles in cancer (Figure 5) and represent potential markers to predict the response to immune checkpoint therapy [51,79-81]. These molecules may also serve as novel targets for the development of preventive and/or therapeutic agents for cancer.

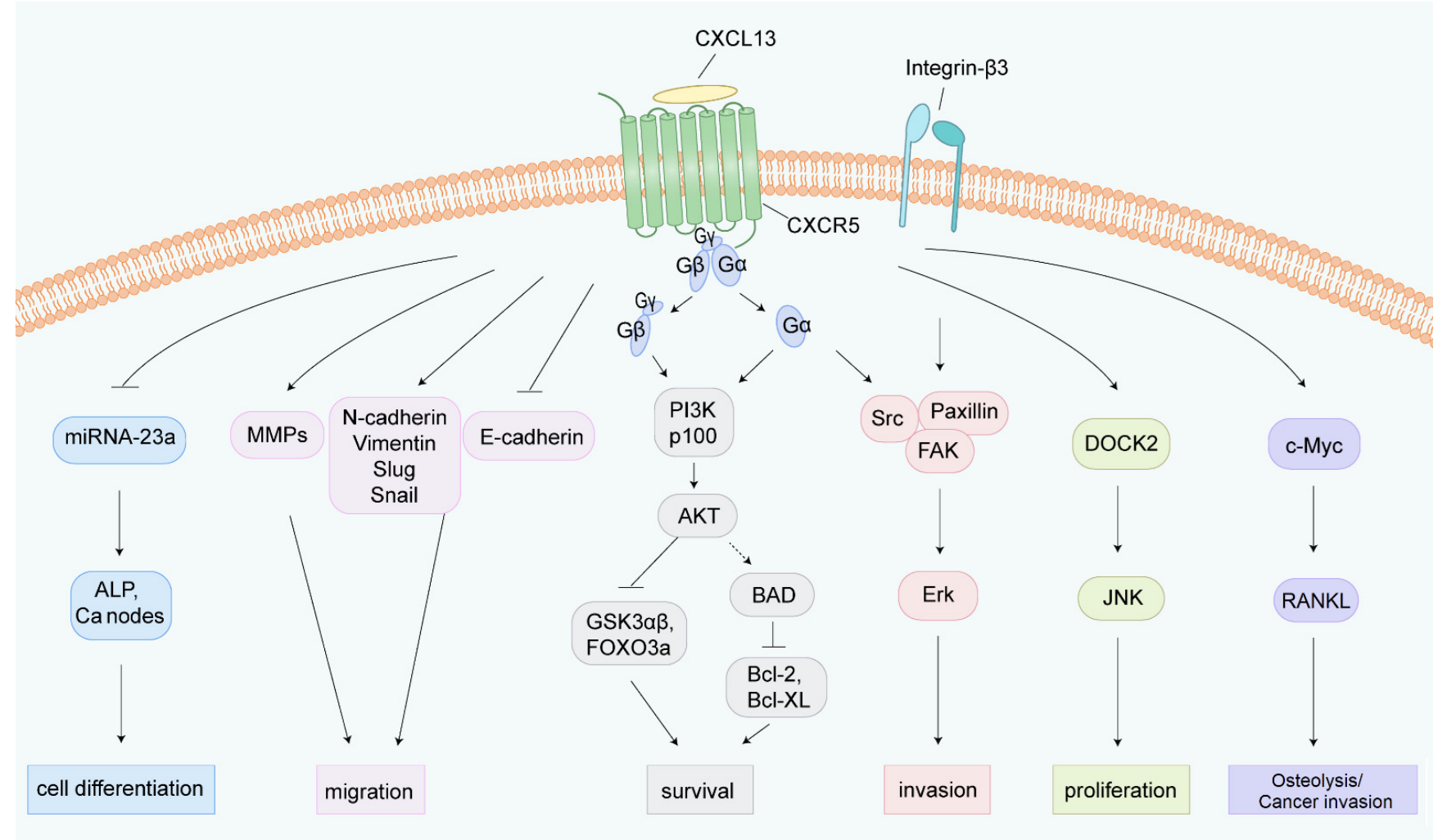

Figure 4. Illustration of the underlying mechanisms of the CXCL13/CXCR5 axis in cell fate determination. The CXCL13/CXCR5 axis triggers multiple intracellular signal transduction pathways. After CXCL13 binds to CXCR5, G proteins dissociate from CXCR5, dividing into $G \alpha$ and $G \beta \gamma$, thereby inducing different downstream molecular events [20,23]. CXCL13 promotes osteogenic differentiation by inhibiting miRNA-23a, inducing ALP activity, and calcium node formation [82]. Upregulation of MMPs, N-cadherin, Vimentin, Slug, and Snail, and downregulation of E-cadherin under CXCL13 treatment enhances tumor cell migration [18,83]. The CXCL13/CXCR5 axis activates PI3K/Akt, integrinB3/Src/Paxillin/FAK, and the DOCK/JNK pathway to induce cell survival, invasion, and proliferation, respectively [73]. CXCL13 increases the phosphorylation of c-Myc and c-Jun, and upregulates the transcriptional regulator NFATc3, which binds to the promoter region of RANKL and elevates the expression of RANKL [74,84]. ALP, alkaline phosphatase; Ca, calcium; MMPs: matrix metalloproteinase; BAD, Bcl-2 agonist of cell death; FAK, focal adhesion kinase; DOCK2, dedicator of cytokinesis 2; JNK, c-Jun kinase; RANKL, receptor activator of NF-kB ligand. 


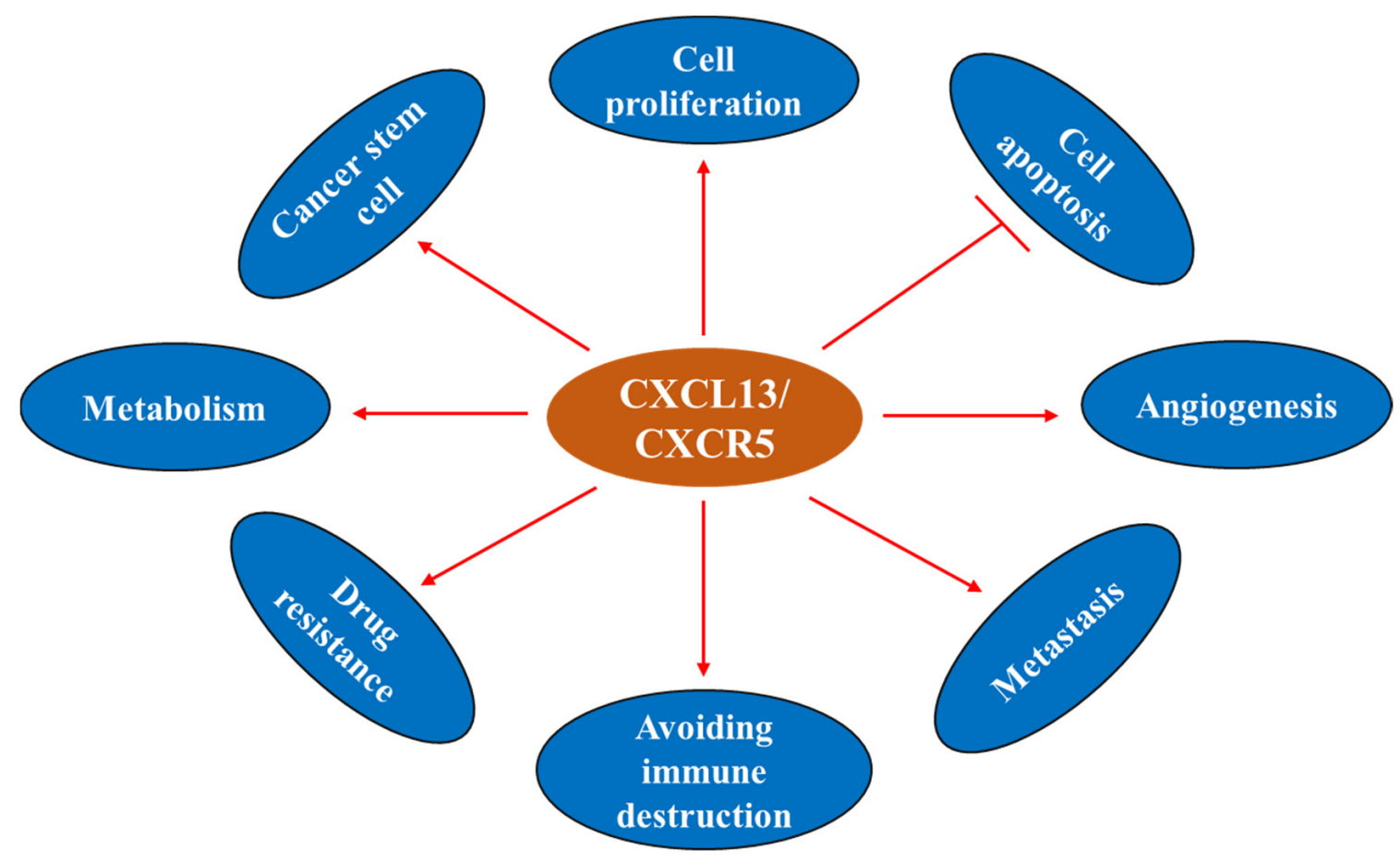

Figure 5. CXCL13 and cancer hallmarks.

\subsection{CXCL13 Sources within the Tumor and the Tumor Microenvironment}

\subsubsection{CXCL13: Cellular Sources within TME}

CXCL13 is secreted by multiple populations of cells within the TME, including stromal cells, endothelial cells, lymphocytes, and tumor cells. FDC, a considerable stromal cell population, is the major producer of CXCL13 in the GCs $[85,86]$. Cancer-associated fibroblasts can convert to myofibroblasts and secrete CXCL13 into the TME upon hypoxia and TGF- $\beta$ stimulation [87]. CXCL13 is also produced by human bone marrow endothelial (HBME) cells [88], Tfh that have infiltrated into tumor tissues [89], $\mathrm{PD}^{+} \mathrm{CD} 8^{+} \mathrm{T}$ cells [90], the TGF $\beta$ dependent $\mathrm{CD}_{103}{ }^{+} \mathrm{CD}^{+}$tumor-infiltrating T-cell (TIL) subpopulation [91], neoplastic $\mathrm{T}$ cells [85], and several types of tumor cells.

\subsubsection{CXCL13: Production under Carcinogen Stimulation}

Environmental carcinogens can induce the production of CXCL13. Studies showed that the expression of CXCL13 at both the mRNA and protein levels was increased in B cell areas of lymphoid follicles in the lungs of cigarette smoke (CS)-exposed mice, and the CS-induced upregulation of CXCL13 was confirmed in patients with COPD. Interestingly, CS-induced formation of pulmonary lymphoid follicles was blocked by anti-CXCL13 antibodies in mice, and the absence of tertiary lymphoid organs (TLOs) in bronchoalveolar lavage alleviated the inflammatory response and destruction of the alveolar walls but did not impact the remodeling of the airway wall [45].

CXCL13 plays a critical role in environmental carcinogenesis. Wang et al. [18] screened for abnormal inflammatory factors in patients with non-small cell lung cancers (NSCLCs) from Xuanwei city in China's Yunnan Province, where the wide use of smoky coal resulted in severe household air pollution, and found that CXCL13 was substantially upregulated in $63(90 \%)$ of 70 Yuanwei patients with NSCLC. In NSCLC patients from control regions where smoky coal was not used, CXCL13 was overexpressed in 44/71 (62\%) of smoker patients and 27/60 (45\%) of non-smoker patients [18]. Benzo(a)pyrene (BaP), a polycyclic aromatic hydrocarbon (PAH) carcinogen found in tobacco smoking and haze (smohaze) [92], can be metabolically activated by the production of BaP-7,8-diol-9,10epoxides (BPDEs). BPDE reacts with DNA to form adducts at $N^{2}$ of deoxyguanosine 
(BPDE-N2-deoxyguanosine), which induces mainly $\mathrm{G} \rightarrow \mathrm{T}$ genomic mutations to promote carcinogenesis [93]. We found that BaP induced the production of CXCL13 by lung epithelial cells in vitro and in vivo. Consistent with these observations, CXCL13 was shown to be elevated in serum samples of current and former smokers and was associated with lung cancer risk [94]. CXCL13 induces the production of secreted phosphoprotein 1 (SPP1 or osteopontin) by macrophages to activate $\beta$-catenin and induce an epithelial-tomesenchymal transition (EMT) phenotype (Figure 6). Deficiency in CXCL13 or CXCR5 significantly suppressed BaP-induced lung cancer in mice, indicating that CXCL13 plays a key role in smohaze carcinogen-induced lung cancers [18,92]. CXCL13 is also upregulated in human colorectal cancer and is secreted by dendritic cells [95]. The carcinogen azoxymethane, which is catalyzed into methylazoxymethanol to induce $\mathrm{G} \rightarrow \mathrm{A}$ genomic mutations, induces colorectal cancer in vivo. Interestingly, knockout of CXCL13 inhibits azoxymethane/dextran sodium sulfate-induced colorectal cancer in mice [95]. These data suggest a crucial role for the CXCL13-CXCR5 axis in cancers induced by environmental factors and could be a novel target for the development of preventive and therapeutic agents to combat related cancers.

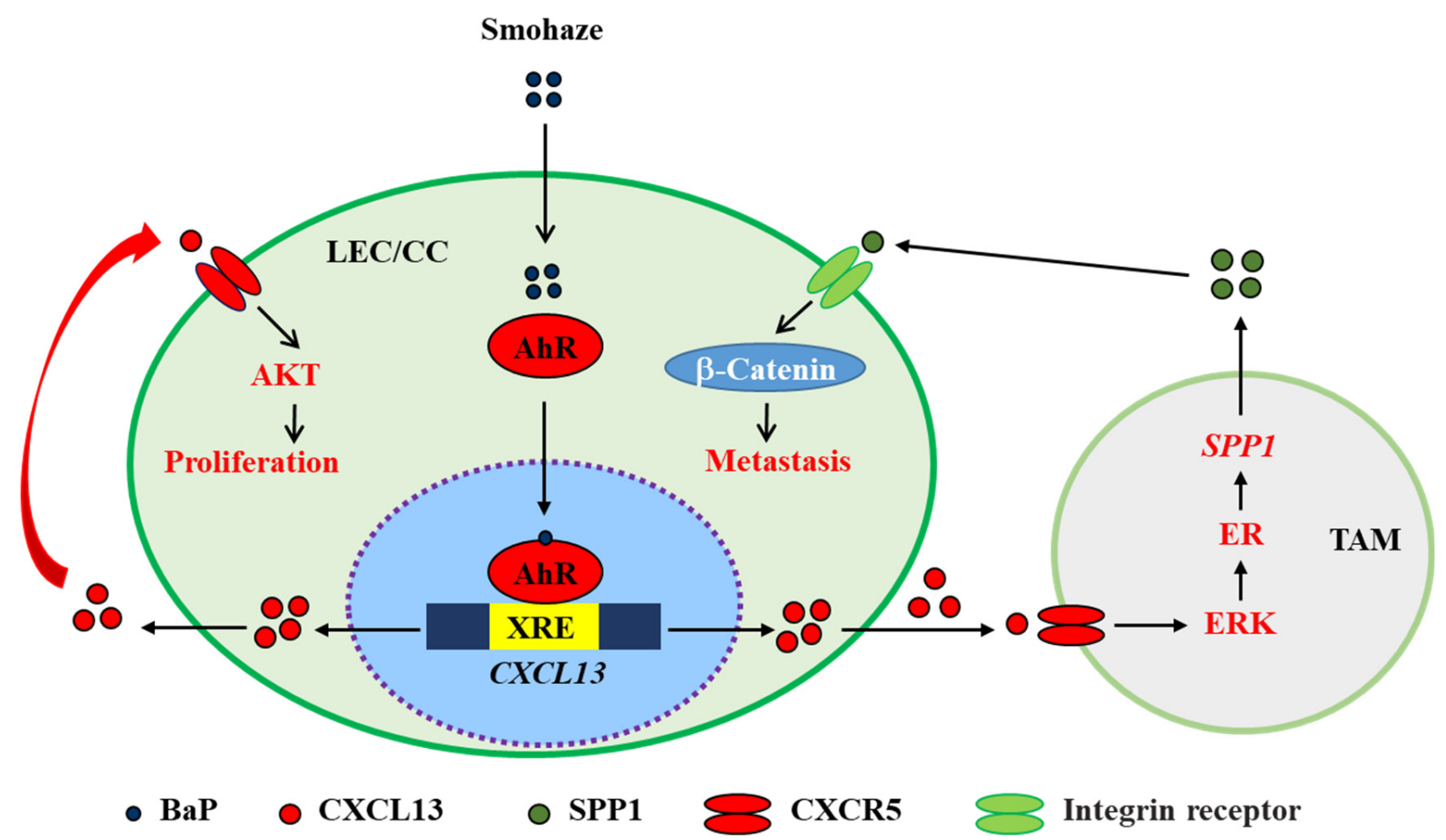

LEC, lung epithelial cells; CC, cancer cells; TAM, tumor-associated macrophages

Figure 6. Schematic representation of smohaze-induced production of CXCL13 in lung cancer.

\subsection{CXCL13/CXCR5 and Cancer Hallmarks}

\subsubsection{CXCL13 and Cell Proliferation}

CXCL13 binds specifically to CXCR5, which couples with MEK/ERK to induce cell proliferation [96]. In clear cell renal cell carcinoma (ccRCC) cells, CXCL13 promotes proliferation by binding to CXCR5 and subsequently activating the PI3K/AKT/mTOR signaling pathway [97]. The PI3K/AKT pathway also plays a key role in the CXCL13/CXCR5 axis, promoting colon cancer growth and invasion $[98,99]$. The CXCL13/CXCR5 axis promotes the proliferation and invasion of prostate cancer (PCa) cells by activating JNK, ERK, SRC/FAK, PI3K, and Akt $[73,96,100]$. CXCL13 also promotes the proliferation of androgen-responsive LNCaP PCa cells in a JNK-dependent, DOCK2-independent manner, whereas in androgen-independent PC 3 cells, CXCL13-induced proliferation is dependent 
on DOCK2 [73,100,101]. CXCL13/CXCR5 also promotes cell cycle progression from the G1 to the $S$ phase in PCa cells by the inactivation of CDKN1B and the activation of Cdk2 [73]. In addition, CXCL13 is involved in the progression of breast cancer cells through the CXCR5/ERK pathway [102]. Therefore, the CXCL13/CXCR5 axis plays a key role in regulating the proliferation of many cancer cells and could be a valuable therapeutic target.

\subsubsection{CXCL13 and Cell Apoptosis}

The CXCL13/CXCR5 axis plays an important role in cell homeostasis, as well as helping leukemic cells escape apoptosis by regulating chemokine-induced signaling [103]. In breast cancer cells, the decrease in CXCL13 leads to the decreased expression of CXCR5, p-ERK/ERK, and cyclin D1 as well as the increased expression of cleaved Casp-9, which is an initiator caspase protease for apoptosis [104]. Moreover, CXCL13/CXCR5 has been demonstrated to induce significant resistance to TNF- $\alpha$-mediated apoptosis in B cell lineage acute and chronic lymphocytic leukemia (B-ALL and B-CLL) $[105,106]$. CXCL13 regulates the phosphorylation of Bcl-2 (at Serine 70), Bcl-xL (at Serine 62), and BAD (at Serine 112 and 136) in PC3 cells to exert anti-apoptotic effects [73]. CXCR5 may be involved in the protection of retinal pigment epithelium (RPE) and retinal cells from aging-related photoreceptor apoptosis [107]. These data demonstrate that the CXCL13/CXCR5 axis can confer the evasion of apoptosis in cancer cells by modulating p-ERK/ERK, TNF- $\alpha$, Casp-9, and other signal pathways.

\subsubsection{CXCL13 and Cancer Stem Cell (CSC)}

Cancer stem cell (CSC) is a type of tumor cell with the abilities of self-renewal, differentiation, and high drug resistance [108]. IL30 overproduction by prostate cancer stem cell-like cells promotes tumor initiation and development, which involves increased proliferation, vascularization, and myeloid cell recruitment. Moreover, it promotes stem cell-like cell dissemination to lymph nodes and bone marrow by upregulating the CXCR5/CXCL13 axis [109]. CXCL13 recruits B cells to prostate tumors to promote castrate-resistant cancer progression by producing lymphotoxin, which activates an IkB kinase $\alpha$ (IKK $\alpha$ )-BMI1 module in prostate cancer stem cells [110]. The role of the CXCL13/CXCR5 pathway in the cancer stem cells of other malignancies remains to be investigated.

\subsubsection{CXCL13 and Drug Resistance}

CXCL13/CXCR5 plays an essential role in drug resistance. In multiple myeloma (MM), CXCL13 secreted by mesenchymal stem cells (MSCs) confers resistance to bortezomib to MM cells [111]. In 5-fluorouracil (5-Fu)-resistant colorectal cancer patients, serum CXCL13 is elevated, and a high CXCL13 concentration is associated with a worse clinical outcome [112]. CXCL13 is significantly increased in diffuse large B-cell lymphoma resistance to chemotherapy and is involved in tumor progression [113]. CXCR5 is overexpressed in mantle cell lymphoma (MCL), where it mediates MCL-stromal cell adhesion and drug resistance. The drug resistance of MCL is associated with increased expression of B-cell activation factor (BAFF), which induces the expression of CXCL13 [114].

\subsubsection{CXCL13/CXCR5 in the Tumor Microenvironment}

The CXCL13/CXCR5 axis may have different roles in the TME. In leukemia, prostate, lung, pancreatic, colon, and gastric cancers, CXCL13 exhibits pro-cancer effects by recruiting B cells [86,87,115,116], CD68 ${ }^{+}$macrophages [18], regulatory B cells (Bregs) $[117,118]$, Treg [119], and CD40 ${ }^{+}$MDSCs [120], shaping an immune-suppressive TME to trigger tumorigenesis and tumor progression (Figure 7A). A few reports regarding breast and lung cancers have shown that the CXC13/CXCR5 axis attracts B cells and Tfh $[89,90]$ to shape the TLS in the peritumoral or tumor sites (Figure 7B), which is associated with adaptive anti-tumor humoral responses and predicting responses to PD-1 blockade therapy. 


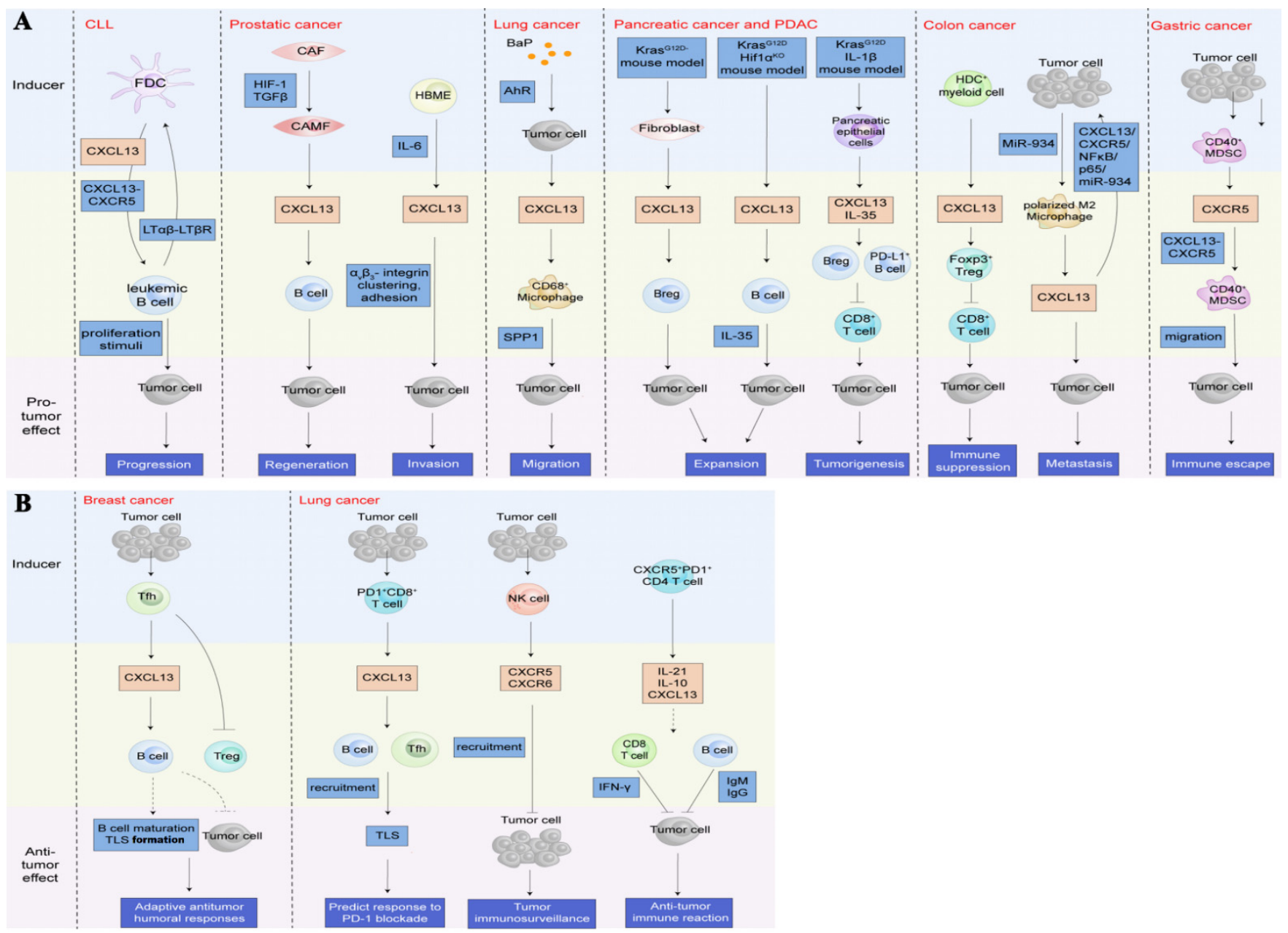

Figure 7. Roles of the CXCL13/CXCR5 axis in the tumor microenvironment (TME). (A). The CXCL13/CXCR5 axis plays a crucial role in shaping a complex TME by recruiting multiple types of lymphocytes to beget pro-tumor or anti-tumor immunity reactions. In the context of pro-neoplastic reactions, the CXCL13/CXCR5 axis attracts B cells to induce tumor progression, regeneration, and invasion [86,87,115,118], or recruits CD68 ${ }^{+}$macrophages [18], Breg [117,118], Treg [119], and $\mathrm{CD} 40^{+}$MDSC [120] to trigger migration, expansion and tumorigenesis, immune suppression, and immune escape, respectively. (B). In the circumstance of anti-tumor reactions, the CXC13/CXCR5 axis recruits B cells and Tfh [89,90] to format TLS in the peritumoral or tumor sites, which is associated with adaptive anti-tumor humoral responses and predicting the response to PD-1 blockade therapy. Additionally, lymphocytes directly or indirectly dampen tumors by the upregulation of CXCL13 and/or CXCR5 [15,121]. CLL, chronic lymphocytic leukemia; LT $\alpha \beta$, lymphotoxin $\alpha 1 \beta 2$; LT $\beta R$, lymphotoxin- $\beta$ receptor; CAF, cancer-associated fibroblasts; CAMF, cancer-associated myofibroblasts; HIF-1, hypoxia-inducible factor 1; TGF $\beta$, transforming growth factor- $\beta$; HBME, human bone marrow endothelial; IL, interleukin; BaP, benzo(a)pyrene; AhR, Aryl hydrocarbon receptor; SPP1, secreted phosphoprotein 1; PDAC, pancreatic ductal adenocarcinoma; Breg, regulatory B cells; HDC, histidine decarboxylase; Treg, regulatory T cells; MDSC, myeloid-derived suppressor cells; Tfh, follicular helper T cells; NK cell, natural killer cell.

Increasing evidence indicates that the CXCL13/CXCR5 axis influences lymphocyte infiltration in the TME by regulating cell interactions [96]. CXCL13 plays a key role in the microenvironment of diffuse large B-cell lymphoma (DLBCL) [113]. In NSCLC, intratumoral CD8 ${ }^{+} \mathrm{T}$ lymphocyte populations with a high level of PD-1 $\left(\mathrm{PD}-\mathrm{1}^{\mathrm{T}}\right)$ express higher levels of CXCL13 and secrete more CXCL13 than CD8 ${ }^{+}$T cells with intermediate $\left(\mathrm{PD}-1^{\mathrm{N}}\right.$ ) and no PD-1 expression (PD-1 ${ }^{-}$). These PD- $1^{\mathrm{T}}$ tumor-infiltrating lymphocytes play an active role in the recruitment of immune subsets to the TME via the secretion of CXCL13 and show predictive potential for response to PD-1 blockades [90]. NSCLC patients also have higher levels of serum CXCL13 as compared to healthy controls. Upon CXCL13 
stimulation, NSCLC cells with a high level of CXCR5 expression exhibit a pro-migratory phenotype [96]. In prostate cancer, CXCL13/CXCR5 interactions promote the progression of tumor cells, including proliferation and metastasis, which are triggered by multiple signaling cascades, such as ERK, PI3K/Akt, stress-activated protein kinase (SAPK)/c-Jun kinase (JNK), Rac, and protein kinase C epsilon (PKCE)/nuclear factor kappa B (NFКB) $[100,101,122,123]$. Intratumoral CXCL13 ${ }^{+} \mathrm{CD}^{+} \mathrm{T}$ cells orchestrate immune-evasive actions, which consist of increased regulated Tregs and exhausted cytotoxic $\mathrm{T}$ cells in gastric cancer [124]. These intratumoral CXCL13 ${ }^{+} \mathrm{CD} 8^{+} \mathrm{T}$ cells are associated with poor clinical outcomes and a decreasing response to chemotherapy. CXCL13/CXCR5-mediated recruitment of $\mathrm{CD} 40^{+}$myeloid-derived suppressor cells (MDSCs) might induce the immune escape of gastric tumors through inhibiting recruitment of T cells in the TME [120]. Recently, Cabrita et al. [51] found that the coexistence of tumor-associated $\mathrm{CD}^{+} \mathrm{T}$ cells and $\mathrm{CD} 20^{+}$ $B$ cells improved survival in patients with metastatic melanomas; immunofluorescence staining of CXCR5 and CXCL13 in combination with CD20 showed the formation of TLSs in these $\mathrm{CD} 8^{+} \mathrm{CD} 20^{+}$tumors.

\subsubsection{CXCL13 and Angiogenesis}

Angiogenesis is a distinguishable characteristic of successful tumor growth in all solid tumors, and CXC chemokines are pleiotropic in their ability to regulate tumor-associated angiogenesis, as well as cancer cell metastases [125]. Chronic hypoxia increases the expression of CXCL13 in adipocytes [65] and promotes the metastasis of prostate cancer by increasing the expression of CXCL13 in tumor myofibroblasts [87]. Fibroblast growth factor-2 (FGF2) is a member of the family of the heparin-binding FGF growth factors with pro-angiogenic activity. CXCL13 inhibits FGF2-induced chemotaxis and proliferation, as well as the survival of endothelial cells, acting as an angiostatic chemokine [126]. CXCL13/CXCR5 axis also facilitates angiogenesis during rheumatoid arthritis progression [127].

\subsubsection{CXCL13 and Immunometabolic Responses}

An integrated immunometabolic response during negative energy balance is required for host survival, and the impacts of nutritional status on immune responses remain to be determined. Recent studies have shown that temporary fasting significantly reduces the number of lymphocytes in Peyer's patches, whose cellular composition is conspicuously altered after resuming feeding, with the numbers seemingly restored. In this process, nutritional signals are necessary to maintain CXCL13 expression by stromal cells [128]. Fasting reduces the numbers of circulating monocytes, as well as monocyte metabolic and inflammatory activity, while hepatic energy-sensing regulates homeostatic monocyte numbers via CCL2 production [129]. However, the potential roles CXCL13 plays in cancer metabolism remain to be investigated.

\subsubsection{CXCL13 and Cancer Metastasis}

More than $90 \%$ of cancer deaths are attributed to metastasis. The intricate interactions of a chemokine and its receptor play an essential role in tumor metastasis. CXCL13/CXCR5 also participates in the metastasis of multiple cancers. CXCL13 enhances cancer metastasis signaling in an autocrine or paracrine manner, since it is secreted by tumor cells or other cell types, such as stromal cells and lymphocytes. In a murine prostate cancer model, which exhibits PKC $\varepsilon$ overexpression and Pten deficiency, the release of CXCL13 by tumor cells was upregulated in a non-canonical NF- $\mathrm{KB}$ pathway, boosting tumor cells' migratory properties [122]. CXCL13 facilitates breast cancer cell line migratory activity via the nuclear factor kappa-B ligand (RANKL)-Src pathway, which mediates the upregulation of EMT regulators and matrix metalloproteinase-9 (MMP9) [83,130]. CXCL13, also secreted by stromal cells, upregulates the expression of RANKL on stromal cells, promoting tumor cell migration and lymph node metastasis via the RANK-RANKL pathway [131]. CXCL13 mediates distal metastasis of colon cancer by increasing the secretion of MMP13 and the activation of the PI3K/Akt pathway [132]. A further study showed that polarized 
M2 macrophages mediate premetastatic niche formation and facilitate colorectal cancer liver metastasis by forming a positive-feedback loop of CXCL13/CXCR5/NFkB/p65/miR934 [133]. On the other hand, CXCL13 recruits CXCR $5^{+} \mathrm{CD} 68^{+}$macrophages secreting SPP1, which triggers tumor cell migration through the EMT pathway in lung cancer [18]. The endpoint of facilitating metastasis may arouse enthusiasm in pursuing CXCL13/CXCR5 as a potential target for cancer therapy.

\subsection{Regulation of CXCL13 in Tumors}

A series of studies have shed new light on the regulation of CXCL13 and CXCR5 in tumors. RelA, a subunit of the NF-kB family [134], directly binds to the CXCL13 promoter and positively regulates the transcription of CXCL13, while nuclear factor erythroid 2-related factor 2 (NRF2) acts as a negative transcriptional regulator of this chemokine [135]. CXCR5 was positively regulated by RelA and negatively by p53 [135,136], and nuclear raf-1 kinase regulates the CXCR5 promoter by associating with NFATc3 [137]. P53 homologues, p63 and p73 [138], utilize the same mechanism by which the activity of NFkB is attenuated to reduce the expression of CXCR5 [139]. The aryl hydrocarbon receptor (AhR), a ligand-activated transcription factor, is translocated to the nucleus under $\mathrm{BaP}$ stimulation and binds to the xenobiotic-responsive element (XRE) in the promoter of CXCL13, positively regulating the transcription of CXCL13 (Figure 6) [18]. Another transcription regulator, interferon regulatory factor 5 (IRF5), directly targets CXCL13 by binding to its promoter and upregulating CXCL13 expression [17]. CXCL13 is also identified as a downstream target gene of the transcription factor androgen receptor (AR) [140]. In addition, oncoprotein PKC $\varepsilon$ overexpression with tumor suppressor Pten deficiency boosts the expression of CXCL13 individually and synergistically through the non-canonical NF- $\mathrm{kB}$ pathway [122]. In a murine Kras ${ }^{G 12 D}$ Hif1 $\alpha$ knockout model with $L S L-\mathrm{Kras}^{+/ G 12 \mathrm{D}}$ and Pdx1-cre with interleukin$1 \beta$ (IL-1 $\beta$ ) overexpression, the increase in CXCL13 levels depends on the combination of HIF1 $\alpha$ and Kras, as well as the cooperation of IL-1 $\beta$ and Kras $[117,118]$. However, the mechanisms of CXCL13 upregulation in both murine models have not been elucidated.

\section{CXCL13/CXCR5 in Several Cancer Types}

Mounting evidence demonstrates a high concentration of CXCL13 and/or high expression of CXCR5 in tumor tissues or tumor cell lines. The CXCL13/CXCR5 axis in both hematological malignancies and solid tumors mediates multiple intracellular signal cascade reactions and yields various phenotypes responding to the signaling pathways. In addition, the CXCL13/CXCR5 axis also potentiates the crosstalk between tumor cells and lymphocytes or non-lymphocytes, shaping a complex TME. The roles of the CXCL13/CXCR5 axis participating in the malignant tumors are context-dependent, including pro-tumor and anti-tumor activities (Figure 7). On one hand, CXCL13 attracts immunosuppressive cells to mediate immune suppression or evasion, leading to tumor progression, while on the other hand, the CXCL13/CXCR5 axis elicits tumoricidal immunity signaling to escape tumor immunosurveillance in some cancer types $[54,89,141]$ (Table 1$)$. 
Table 1. Therapeutic targets associated with the CXCL13/CXCR5 axis in malignancies and the tumor microenvironment.

\begin{tabular}{|c|c|c|c|c|c|c|}
\hline Target & $\begin{array}{c}\text { Cancer } \\
\text { Type }\end{array}$ & Function & Approach & $\begin{array}{l}\text { In Vivo or } \\
\text { In Vitro }\end{array}$ & Outcome & Refs. \\
\hline CXCL13 & $\begin{array}{c}\text { Prostate } \\
\text { cancer }\end{array}$ & $\begin{array}{l}\text { Induction of prostate cancer } \\
\text { cell proliferation and migration }\end{array}$ & $\begin{array}{l}\text { siRNA and shRNA; } \\
\text { antibody }\end{array}$ & In vivo; in vitro & $\begin{array}{l}\text { Inhibiting tumor } \\
\text { growth and metastasis }\end{array}$ & [122] \\
\hline CXCL13 & $\begin{array}{l}\text { Prostate } \\
\text { cancer }\end{array}$ & $\begin{array}{l}\text { Chemotaxis B cells into } \\
\text { regressing tumor }\end{array}$ & Antibody & In vivo & $\begin{array}{l}\text { Preventing B-cell } \\
\text { recruitment into tumor } \\
\text { under castration }\end{array}$ & [115] \\
\hline CXCL13 & $\begin{array}{l}\text { Breast } \\
\text { cancer }\end{array}$ & $\begin{array}{c}\text { Activating CXCR5/ERK } \\
\text { pathway }\end{array}$ & Polyclonal antibody & In vivo; in vitro & $\begin{array}{l}\text { Attenuating tumor } \\
\text { volume and growth; } \\
\text { inhibiting tumor cell } \\
\text { proliferation and } \\
\text { promoting its apoptosis }\end{array}$ & {$[102,104]$} \\
\hline CXCL13 & $\begin{array}{l}\text { Breast } \\
\text { cancer }\end{array}$ & $\begin{array}{l}\text { Enhancing the production of } \\
\text { RANKL on tumor cells and } \\
\text { the interaction between ILC } 3 \\
\text { and stromal cells }\end{array}$ & Antibody & In vivo & $\begin{array}{l}\text { Attenuating lymph } \\
\text { node metastasis }\end{array}$ & [131] \\
\hline CXCL13 & $\begin{array}{l}\text { Lung } \\
\text { cancer }\end{array}$ & $\begin{array}{c}\text { Promotion of cell } \\
\text { proliferation; inducing } \\
\text { the production of SPP1 } \\
\text { by microphage }\end{array}$ & Cxcl13 ${ }^{-/-}$mice & In vivo & $\begin{array}{l}\text { Decreasing the volume } \\
\text { of } \mathrm{BaP} \text {-induced tumor }\end{array}$ & [18] \\
\hline CXCL13 & PDAC & $\begin{array}{l}\text { Homing B cell into } \\
\text { tumor lesions }\end{array}$ & Antibody & $\begin{array}{l}\text { Mice harbored } \\
\text { Kras }{ }^{2} 12 \mathrm{D} \text { PDEC }\end{array}$ & $\begin{array}{l}\text { Reducing the growth } \\
\text { of orthotopic tumor }\end{array}$ & [116] \\
\hline CXCL13 & $\begin{array}{l}\text { Colon } \\
\text { cancer }\end{array}$ & $\begin{array}{c}\text { Induction 5-Fu resistance } \\
\text { and association with a } \\
\text { worse outcome }\end{array}$ & siRNA & In vitro & $\begin{array}{l}\text { Reducing 5-Fu } \\
\text { resistance }\end{array}$ & [112] \\
\hline CXCR5 & CLL & $\begin{array}{l}\text { CXCR5 }{ }^{+} \text {leukemia } \\
\text { B cells recruited by } \\
\text { CXCL13 to encounter } \\
\text { proliferation stimuli }\end{array}$ & $\begin{array}{c}\text { Cxcr5 } 5^{-1-} \\
\text { E } \mu \text {-Tcl1 mice }\end{array}$ & In vivo & $\begin{array}{l}\text { Attenuating tumor } \\
\text { cell proliferation }\end{array}$ & [86] \\
\hline CXCR5 & $\begin{array}{l}\text { Prostate } \\
\text { cancer }\end{array}$ & $\begin{array}{l}\text { Induction of prostate } \\
\text { cancer cells proliferation } \\
\text { and migration }\end{array}$ & siRNA and shRNA & In vivo; in vitro & $\begin{array}{l}\text { Inhibiting tumor } \\
\text { growth and metastasis }\end{array}$ & [122] \\
\hline CXCR5 & $\begin{array}{l}\text { Lung } \\
\text { cancer }\end{array}$ & $\begin{array}{l}\mathrm{CXCR5}^{+} \mathrm{CD}^{+} 8^{+} \\
\text {macrophages producing } \\
\text { SPP1 to promote } \\
\text { EMT process }\end{array}$ & $\mathrm{Cxcr}^{-1-}$ mice & In vivo & $\begin{array}{l}\text { Decreasing the volume } \\
\text { of } \mathrm{BaP} \text {-induced tumor }\end{array}$ & [18] \\
\hline CXCR5 & OSCC & $\begin{array}{l}\text { Induction RANKL } \\
\text { expression under } \\
\text { CXCL13/CXCR5 axis }\end{array}$ & Antibody & In vitro & $\begin{array}{l}\text { Inhibiting the } \\
\text { expression of RANKL }\end{array}$ & [74] \\
\hline TGF $\beta R$ & $\begin{array}{l}\text { Prostate } \\
\text { cancer }\end{array}$ & $\begin{array}{l}\text { Activating CXCL13- } \\
\text { expressing myofibroblasts }\end{array}$ & SB-431542 & In vivo & $\begin{array}{c}\text { Blocking the initiation } \\
\text { of castration-resistant } \\
\text { prostate cancer }\end{array}$ & [87] \\
\hline NFATc3 & OSCC & $\begin{array}{l}\text { Nuclear translocation } \\
\text { mediated by CXCL13/ } \\
\text { CXCR5 axis to bind to } \\
\text { RANKL promoter region }\end{array}$ & siRNA & In vitro & $\begin{array}{c}\text { Preventing } \\
\text { RANKL expression }\end{array}$ & [74] \\
\hline Myofibroblasts & $\begin{array}{l}\text { Prostate } \\
\text { cancer }\end{array}$ & $\begin{array}{l}\text { Induction of } \\
\text { CXCL13 expression }\end{array}$ & $\begin{array}{l}\text { Immunodepletion; } \\
\text { phosphodiesterase } 5\end{array}$ & In vivo & $\begin{array}{l}\text { Blocking the initiation } \\
\text { of castration-resistant } \\
\text { prostate cancer }\end{array}$ & [87] \\
\hline
\end{tabular}

ILC3, ROR $\gamma \mathrm{t}^{+}$innate lymphoid cell group 3; SPP1, secreted phosphoprotein 1; BaP, benzo(a)pyrene; PDAC, pancreatic ductal adenocarcinoma; PDEC, pancreatic ductal epithelial cells; 5-Fu, 5-Fluorouracil; CLL, chronic lymphocytic leukemia; EMT, epithelial to mesenchymal transition; OSCC, oral squamous cell carcinomas; RANKL, RANK ligand; TGF $\beta$ R, TGF $\beta$ receptor; NFATc3, nuclear factor of activated T cells.

\subsection{Chronic Lymphocytic Leukemia and Lymphoid Neoplasms}

\subsubsection{Chronic Lymphocytic Leukemia}

Chronic lymphocytic leukemia (CLL) is the most frequently diagnosed subtype of leukemia in adults and is a lymphoproliferative disorder that is characterized by the expansion of monoclonal, mature $\mathrm{CD}^{+} \mathrm{CD}^{2} 3^{+} \mathrm{B}$ cells in the peripheral blood, secondary lymphoid tissues, and bone marrow. Most CLL tumor cells are inert and arrested in the G0/G1 of the cell cycle, and there is only a small proliferative compartment; however, the progressive accumulation of malignant cells will ultimately lead to symptomatic disease [142,143]. CLL patients express high levels of membrane CXCR5 on leukemic cells and have an elevated serum concentration of CXCL13 when compared with healthy donors [142,143]. In the murine $E \mu$-Tcl1 model of CLL, the CXCR5-expressing malignant $B$ cells are trafficked to GC light zones of B cell follicles in SLOs, where leukemic B cells contact FDCs [86]. Leukemic B cell-associated LT $\alpha \beta$ activates LT $\beta R$ on the FDCs [26,144], which maintains FDC development and structure. Reciprocally, FDCs secrete CXCL13, leading to the potentiation of the CXCL13/CXCR5 axis-mediated malignant B cell attraction 
and proliferation of leukemic $B$ cells [86]. This crosstalk is repressed by the inhibition of the LT $\alpha \beta$-LT $\beta$ R or CXCL13/CXCR5 signaling cascades, resulting in attenuation of CLL progression [86]. In addition to potentiating tumor-stromal cell crosstalk, the CXCL13/CXCR5 axis exerts intracellular signaling cascade reactions, which are conducive to malignant cell survival and resistance to apoptosis. When stimulated with CXCL13, CLL B cells commit to actin polymerization, CXCR5 endocytosis, and the activation of $\mathrm{p} 44 / \mathrm{p} 42$ mitogen-activated protein kinase (MAPK) [143]. CXCL13, as well as other homeostatic chemokines, including CXCL12, CCL21, and CCL19, make crucial contributions to B-CLL cell survival through phosphorylating MAPK extracellular signal-regulated kinase (ERK)1/2, p90RSK, and protein kinase $B(A k t)$, and inhibiting phosphorylation of the downstream effectors GSK $3 \alpha / \beta$ and FOXO3a [103]. The malignant $B$ cells from CLL or acute lymphocytic leukemia (ALL) patients take advantage of the CXCR5/CXCL13 axis and the CCR7/CCL19 axis for resistance to TNF $\alpha$-induced apoptosis via upregulation of paternally expressed gene 10 (PEG10) and subsequent stabilization of caspase-3 and caspase-8 [105]. Taken together, the CXCL13/CXCR5 axis assists B-CLL cell migration, localization, survival, and expansion in the microenvironment of SLOs.

\subsubsection{Lymphoid Neoplasms}

Lymphoid neoplasms, characterized by the malignant clonal proliferation of lymphocytes, such as mature B cells, T cells, and natural killer (NK) cells, are classified as Hodgkin's lymphoma (HL) and non-Hodgkin's lymphoma (NHL), according to morphologic and immunologic characteristics $[145,146]$. Most lymphoid neoplasms are not remediable and eventually relapse after conventional treatment, a phenomenon in which the interaction between malignant lymphocytic cells and resident stromal cells exert a dominant influence [142]. The CXCL13/CXCR5 axis plays pivotal roles in the dissemination and accumulation of malignant lymphocytic cells and in shaping such a tumor-stromal cell microenvironment interaction network [147-149]. The expression level of CXCL13 and CXCR5 are dramatically elevated in NHL [150-154]. A plethora of functional evidence has demonstrated that CXCL13 and/or CXCR5 participate in the pathogenesis of lymphoma, including mantle cell lymphoma (MCL) [155], follicular lymphoma (FL) [156], diffuse large B-cell lymphoma (DLBCL) [156], primary intraocular lymphoma (PIOL) [157], primary central nervous system lymphoma (PCNSL) [158-160], extranodal natural killer (NK)/Tcell lymphoma (ENKTL) [161], and angioimmunoblastic T-cell lymphoma (AITL) [162,163]. Not only do the CXCL13 ${ }^{+}$and/or CXCR5 ${ }^{+}$malignant lymphocytes (B cells and Tfh cells) promote the accumulation and proliferation of lymphoma cells, but so do the CXCL13 ${ }^{+}$ FDC and circulating CXCR5 ${ }^{+} \mathrm{CD}^{+} \mathrm{T}$ cells $[16,85]$. CXCL13 is also involved in lymphoproliferative disorders and lymphoid follicular formation in cutaneous B-cell lymphoma (CBCL) [164,165] and H. pylori-induced gastric mucosa-associated lymphoid tissue (MALT) lymphomas [68,69]. Due to the function of CXCL13 in lymphoma, mounting studies have demonstrated that CXCL13 serves as a useful marker for the diagnosis and prognosis of PCNSL [158], AITL [162,163], MCL [155], PIOL [157], and ENKTL [161].

\subsection{Lung Cancer}

Chronic inflammation provides a favorable context for lung carcinogenesis [166]. CXCL13 has a higher concentration in the serum of NSCLC patients who have had a history of smoking, as compared with those with COPD [167]. The elevated level of CXCL13 in the serum serves as a risk factor for the progression of the early stages of lung adenocarcinoma $[94,168]$. In NSCLC cells, a study showed that the expression of CXCR5 in the nucleus is higher than that in the cell membrane [169]. CXCL13 could be used to determine the origin of squamous cell lung cancer in patients with head and neck squamous cell carcinoma (HNSCC), where a risk for lung metastasis exists [170]. Consistently, NCIH1915 cells with a higher level of CXCR5 expression show more potential to migrate in response to CXCL13 compared to SW-1271 cells with a lower level of CXCR5 [169]. The CXCL13/CXCR5 axis is associated with polycyclic aromatic hydrocarbon(PAH)-induced 
lung carcinogenesis [18]. Both normal lung epithelial (16HBE) and lung adenocarcinoma (A549) cells show upregulated CXCL13 in a dose- and time-dependent manner when the cells are treated with BaP [18]. Moreover, in the NOD/SCID mice bearing A549Luc-CXCL13 cells, CXCL13 recruits CXCR5 ${ }^{+} \mathrm{CD}^{+} 8^{+}$macrophages to the TME, where macrophages produce secreted phosphoprotein 1 (SPP1) to promote cell migration and tumor progression. Interestingly, deficiency in CXCL13 or CXCR5 significantly inhibits $\mathrm{BaP}$-induced lung cancer in mice, indicating the critical role of this axis in environmental lung carcinogenesis [18].

Anti-tumor activity of the CXCL13/CXCR5 axis has also been reported, which is shown to be able to promote the formation of TLSs and is linked to improved survival of lung cancer patients $[15,54,171]$. CXCL13, produced by $\mathrm{PD}^{+} \mathrm{CD}^{+} \mathrm{T}$ cells, mediates the immune cells recruited to TLSs. As a result, the TLS is infiltrated by CXCR5 $5^{+} \mathrm{CD} 4^{+} \mathrm{T}$ cells, $\mathrm{CD}^{+} \mathrm{Bcl6}^{+} \mathrm{Tfh}$ cells, and B cells [90]. Another study reported that the level of IL-21, IL-10, and CXCL13 are upregulated in PD- $1^{+}$CXCR5 ${ }^{+}$CD4 T cells in the GCs, which promotes $\mathrm{CD} 8^{+} \mathrm{T}$ cells to produce IFN- $\gamma$, induces the proliferation of B cells, and potentiates B cells to produce $\operatorname{IgM}$ and $\operatorname{IgG}$, forming an anti-tumor immunity microenvironment [15]. Furthermore, the overexpression of CXCR5 on intratumoral natural killer (NK) cells has been speculated to be involved in their migration in the tumor site, where NK cells participate in tumor immunosurveillance [121]. Although CXCL13 mediates the recruitment of immune cells to the TLS in the intra- and extra-tumor regions, the specific functions and molecular mechanisms of these cells still need to be further investigated.

\subsection{Prostate Cancer}

Prostate cancer (PC) represents a leading cause of cancer-related mortality among men due to its metastasis [172]. Chemokines and homologous receptors play a crucial role in the initiation and progression of metastasis in PC. Extensive studies have reported that the CXCL13/CXCR5 axis mediates PC cell migration, invasion, cell adhesion, and anti-apoptosis functions through regulating the intracellular signaling networks in an autocrine or paracrine fashion and forming an oncogenic microenvironment, which consists of multiple cell types, such as inflammatory cells and PC cells. In PC tissues and cell lines, the expression level of CXCR5 is notably increased and positively related to the progression of PC [173]. CXCR5 mediates PC-cell survival and metastasis under CXCL13 stimulation by coupling with specific G protein subunits [20]. CXCL13, highly expressed in PC tissues, is upregulated by AR and mediates PC genesis and development [140]. PKC $\varepsilon$ overexpression with a Pten deficiency upregulates the release of CXCL13, leading to tumorigenesis and metastasis of PC through the CXCL13/CXCR5 axis in an autocrine manner [122]. Based on antibody microarray analysis, the molecular mechanisms of the CXCL13/CXCR5 axis participating in PC cell proliferation and motility mainly include the PI3K/Akt/cyclin-dependent kinases (Cdk)1/2-Cdk inhibitor 1B (CDKN1B), stressactivated protein kinase (SAPK)/c-Jun kinase (JNK), Src/Erk1/2, and integrin $\beta 3$-FAK/SrcPaxillin (PXN) pathways $[73,100,101,140]$. However, the potential of drug targets exploiting these mechanisms to better treat $\mathrm{PC}$ require further validation.

CXCL13 also has an essential role in configuring a complex TME. Although patients initially benefit from the treatment of androgen ablation, the responses are transient with a duration of 12-18 months when they progress to castration-resistant (CR) PC [174-176]. Under androgen ablation therapy, regressing PC is accompanied by cell death and hypoxia, which activates cancer-associated myofibroblasts (CAMF) to secrete CXCL13 by inducing HIF-1 activation and TGF- $\beta$ expression [87]. CXCL13 expressed by myofibroblasts mediates B-cell recruitment into the TME [115].In $\mathrm{J}_{\mathrm{H}}{ }^{-1-}$ mice lacking mature $\mathrm{B}$ cells, the emergence and expansion of castration resistant prostate cancer (CRPC) after androgen ablation relies on $B$ cells, rather than T cells, and the CRPC microenvironment is subsequently infiltrated by $B$ cells [115]. The inflammation-responsive I $\kappa$ B kinase (IKK) $\beta$ in B cells mediates LT $\alpha \beta$ secretion [115]. The interaction between LT $\alpha \beta$ and LT $\beta R$ on PC cells triggers the IKKa-E2F1-BMI1 pathway, which regulates the regeneration of oncogenic prostate stem 
cells $[177,178]$ and phosphorylates STAT3, an anti-apoptosis and oncogenic transcription factor [179], as a result of the reconstruction of PC cells, accelerating the emergence of CRPC [87,115]. Apart from the recruitment of tumor-infiltrating B cells, CXCL13, expressed by interleukin-6 (IL-6)-treated human bone marrow endothelial (HBME) cells, mediates PC-cell invasion, adhesion to HBME cells, and $\alpha_{\mathrm{v}} \beta_{3}$-integrin clustering [88].

\subsection{Breast Cancer}

CXCL13 was found to be overexpressed in breast cancer and in the peripheral blood of patients with breast cancer $[180,181]$. The CXCL13/CXCR5 axis shows anti-tumor and pro-tumor functions. One study showed that the CXCL13/CXCR5 axis was a good prognostic marker for breast cancer $[17,180]$. The CXCL13/CXCR5 axis is related to improved outcomes of human epidermal growth factor receptor 2 (HER2)-positive breast cancer [182]. Another study demonstrated that CXCL13, which is regulated by interferon regulatory factor 5 (IRF5), mediates CXCR5 ${ }^{+} \mathrm{B}$ cells and $\mathrm{T}$ cells homing to tumors, thereby eliciting an anti-tumor immune response $[17,183]$. Infiltrated CD4 ${ }^{+}$Tfh cells express CXCL13, which has been speculated to initiate GC formation and enhance TLS development by homing immune cells to peritumoral or tumor sites $[89,184]$. In addition, these CXCL13-producing Tfh cells reverse Treg-mediated immune suppression and present adaptive anti-tumor humoral responses [89].

However, a large number of studies have demonstrated that the CXCL13/CXCR5 axis is closely associated with breast cancer growth and lymph node metastasis $[83,102,136,185]$. Breast cancer cell lines undergoing CXCL13 stimulation overexpress EMT regulators and MMP9 via the nuclear factor kappa-B ligand (RANKL)-Src pathway, which is critical for breast cancer cell progression and migration $[83,130]$. Breast cancer cells expressing CCL21 also recruit ROR $\gamma \mathrm{t}^{+}$innate lymphoid cell group 3 (ILC3) to the TME, where ILC3 stimulates stromal cells to secrete CXCL13 [131]. CXCL13, in turn, potentiates the interaction between ILC3 and stromal cells, resulting in the increased production of RANKL on stromal cells, which promotes tumor cell migration and lymph node metastasis by the RANK-RANKL pathway [131]. After treatment with an anti-CXCL13 antibody, the levels of transforming growth factor beta-1 (TGF- $\beta 1$ ), interleukin-1 (IL-1), tumor necrosis factor (TNF), p-Erk/Erk, and cyclin D1 in MDA-MB-231 cells were obviously decreased, whereas cleaved caspase-9 was increased, leading to growth inhibition and apoptosis induction of MDA-MB-231 cells [104]. Moreover, in a female BALB/c mouse model of breast cancer, an anti-CXCL13 antibody reduced tumor growth by impairing the CXCR5/Erk pathway and inducing tumor cell apoptosis [102]. A recent study showed that CXCL13 expression is increased in the sera of breast cancer patients with brain metastases [186], though the role and mechanism of action of the CXCL13/CXCR5 axis in cancer metastasis remain to be elucidated.

\subsection{Pancreatic Cancer}

In pancreatic cancer, CXCL13 signaling participates in the establishment of the prooncogenic microenvironment by recruiting tumor-associated B cells [116-118]. The murine Kras ${ }^{G 12 D}$ Hif1 $^{K O}$ model of pancreatic cancer exhibits an abundant expression of CCL19, CCL20, CCL21, CXCL12, and CXCL13, all of which mediate Breg migration and infiltration into tumor tissue to promote pancreatic tumorigenesis [118]. In Kras ${ }^{G 12 D}$-harboring pancreatic ductal adenocarcinoma (PDAC), CXCL13 expression by stromal fibroblasts enhances the infiltration of IL-35 producing B cells into the TME, which potentiates the expansion of pancreatic cancer cells [116]. Recently, the pro-tumor role of B cells in the PDAC has been further complemented. In the PDAC mouse model of LSL-Kras ${ }^{+/ G 12 D}$ and $P d x 1$-cre with IL- $1 \beta$ overexpression, the combination of IL-1 $\beta$ stimulation with Kras mutation mediates the upregulation of CXCL13 expression and the expansion of Breg and PD-L1 ${ }^{+} \mathrm{B}$ cells, which play an immune-suppressive role in inhibiting $\mathrm{CD} 8^{+} \mathrm{T}$ cell activity, in addition to facilitating pancreatic tumorigenesis [117]. These studies indicated that the concentration of CXCL13 might serve as a potential marker for B-cell amplification in 
PDAC, and immunotherapy that targets CXCL13 signaling, or B cells, might enhance the therapeutic efficacy.

\subsection{Colorectal Cancer}

In colorectal or colon cancer, the CXCL13/CXCR5 axis mediates the pathogenesis, development, and distal metastasis of tumor cells through upregulating the expression and secretion of MMP13, as well as activating the PI3K/Akt pathway $[98,125,187,188]$. The CXCL13/CXCR5 axis is also involved in the colorectal TME. The CXCL13/CXCR5 axis in histidine decarboxylase $\left(\mathrm{HDC}^{+}\right)$granulocytic myeloid cells promotes Foxp3 expression, Stat3 phosphorylation, and Treg proliferation, as a result of immune suppression and tumorigenesis [119]. CXCL13 is critical to colorectal cancer pathogenesis, because CXCL13 deficiency and the blockade of CXCL13 signaling ameliorates disease progression. CXCL13 promotes intestinal tumorigenesis through the activation of the AKT signaling pathway in a CXCR5-dependent manner. Translocation of the intestinal microbiota drives CXCL13 production in DCs through the activation of NF- $\mathrm{KB}$ signaling, and inhibition of microbiota translocation decreases CXCL13 production and suppresses intestinal tumorigenesis. The carcinogen azoxymethane/dextran sodium sulfate induces colorectal cancer in mice, whereas knockout of CXCL13 significantly inhibits the induction of colorectal tumorigenesis in vivo by these carcinogens [95]. These results show that the CXCL13-CXCR5 axis is involved in the crosstalk between chemokines and cell growth during the development of colorectal carcinogenesis, which provides a therapeutic strategy for targeting CXCL13/CXCR5 in the future clinical treatment of colorectal cancer.

\subsection{Oral Squamous Cell Carcinoma}

The CXCL13/CXCR5 axis makes prominent contributions to oral squamous cell carcinoma (OSCC) invasion of bone/osteolysis $[74,84,189]$. Overexpression of CXCL13 in the stromal/preosteoblast cells significantly increases the phosphorylation of c-Myc and c-Jun and upregulates the transcriptional regulator NFATc3 [74,84]. Phosphorylated c-Myc (p-C-Myc), p-c-Jun, and NFATc3 bind to the RANKL promoter region and upregulate the expression of RANKL, which participates in osteoclastogenesis and OSCC invasion of the bone $[74,84]$. Inversely, oral cancer-associated TLSs with upregulation of CXCL13 are linked to the extended survival of oral cancer patients, indicating the roles of TLSs as a prognostic marker and immune treatment for oral cancer [190].

\subsection{CXCL13 and Other Cancers}

CXCL13 abounds in the serum and tumor tissue of patients with gastric cancer and serves as a prognostic marker for patients under postoperative adjuvant chemotherapy [14,76,191-193]. The CXCL13/CXCR5 axis drives CD40 ${ }^{+}$MDSC migration to gastric cancer, leading to immune escape and tumor progression [120]. CXCL13 ${ }^{+} \mathrm{CD} 8^{+} \mathrm{T}$ cells mediate immune evasion with increased Treg cells and exhausted cytotoxic T cells [124]. High infiltration of CXCL13 ${ }^{+} \mathrm{CD} 8^{+} \mathrm{T}$ cells in tumor tissue is associated with poor clinical outcomes for the patients, and elimination of these cells could be helpful for gastric cancer immunotherapy. CXCL13 has been reported to be increased in the serum of patients with hepatocellular carcinoma (HCC) $[194,195]$. CXCL13 potentiates the progression of HCC by activating the Wnt/ $\beta$-catenin pathway and promoting IL-12, IL-17, and IgG4 production [194]. The CXCL13/CXCR5 axis has also been reported in the initiation and progression of other solid tumors, such as renal cell carcinoma, neuroblastoma, thyroid cancer, osteosarcoma, ovarian cancer, and melanoma. Taken together, CXCL13 and CXCR5 usually act as oncogenic cascades in the promotion of tumor cell survival, proliferation, migration, and invasion, and represent therapeutic targets for the development of novel anti-cancer drugs. 


\section{Therapeutic Potentials of CXCL13/CXCR5 Axis in Cancer}

\subsection{Therapeutic Effect of Cancer Cells in Targeting CXCL13/CXCR5 or the Downstream Molecules}

The CXCL13/CXCR5 axis makes pivotal contributions to the initiation and progression of tumors, and therefore may serve as an attractive therapeutic target for related malignant neoplasms $[20,104,112]$. Pivotal molecules of the CXCL13/CXCR5 axis may also serve as targets for drug development (Table 1). Intriguingly, utilizing intrakine CXCL13KDEL, which traps CXCR5 in the endoplasmic reticulum, causes a prolonged growth arrest of cancer cells [99]. In breast cancer, an anti-CXCL13 antibody suppressed tumor growth by inhibiting the TGF- $\beta 1$, IL-1, TNF, cyclin D1, and CXCR5/Erk pathways $[81,86]$ and repressed tumor metastasis by inhibiting RANKL production [117]. Anti-CXCL13 antibodies and RNAi were used to treat lung cancer and PDAC $[18,98]$. Small interference RNA (siRNA or shRNA)-mediated silencing of this axis reversed 5-fluorouracil-resistance in colorectal cancer cells or restrained the volume and mass of tumors in murine models [112,122]. A study showed that spebrutinib (CC-292), a small molecular inhibitor of Bruton's tyrosine kinase (BTK), significantly reduces the serum concentration of CXCL13 and shows a therapeutic effect on rheumatoid arthritis [196]. Inhibition of the downstream molecules of the CXCL13/CXCR5 axis, e.g., TGF $\beta R$ and NFATc3, represent an alternative therapeutic strategy for cancers $[103,115,131]$

\subsection{Regulating the Non-Cancerous Cells in the TME by Directly or Indirectly Targeting the CXCL13/CXCR5 Axis}

CXCL13-producing non-cancerous cells in the TME, such as myofibroblasts, myeloid cells, B cells, and T cells, may also serve as potential targets for cancer therapy (Table 1). A previous study demonstrated that blocking the CXCL13/CXCR5 axis using siRNA dampens the recruitment and expansion of Tregs, which exert immunosuppressive effects in the TME [119]. B cells homing into the TME via the CXCL13/CXCR5 axis include protumor B cells and anti-tumor B cells. In pro-neoplastic circumstances, tumor-infiltrating B cells facilitate tumor progression by producing cytokines to enhance cancer cell survival and proliferation $[115,116]$, or by developing immune-suppressive $B$ cells to impair CD8 ${ }^{+}$ $\mathrm{T}$ cell activity [117]. Therapeutic strategies (including anti-CXCL13 antibody) to block $B$ cell recruitment have efficiently hindered cancer progression and prevented cancerassociated myofibroblasts (CAMF) activation by phosphodiesterase 5 (PDE5) inhibitors or by deleting CAMF along with blocking the TGF- $\beta$ receptor kinase [87]. In anti-neoplastic circumstances, $B$ cells engage in responses against tumors by secreting immunoglobulins, activating $\mathrm{T}$ cells, and directly lysing cancer cells $[15,49]$. Emerging evidence has depicted the upregulation of CXCL13 levels in the TLS, where B cells yield the capability of releasing antibodies and presenting antigens to $C D 8^{+} \mathrm{T}$ cells $[190,191]$. An increased interest in developing a responsive biomarker and target for immune checkpoint therapy has focused on the role of B cells and the TLS, which are associated with favorable outcomes for patients after immunotherapy $[51,141,195,197]$. Given the crucial role of CXCL13/CXCR5 signaling in B cell migration and TLS formation, a further understanding of how these processes are regulated by the CXCL13/CXCR5 axis might provide a novel strategy to enhance the response to immune checkpoint blockade therapy.

\section{Concluding Remarks}

The CXCL13/CXCR5 axis plays multifaceted roles in intracellular signaling transduction pathways and interactions among tumor cells, stromal cells, and lymphocytes. The CXCL13/CXCR5 axis not only modulates molecular events inside malignant cells to promote tumor initiation and progression, but also recruits multiple populations of lymphocytes to exert pro-tumor or anti-tumor immunity reactions in the TME. An intriguing phenomenon is that those anti-neoplastic lymphocytes attracted by CXCL13 signaling, such as B cells and Tfh, participate in the organization of the TLS. However, the circumstances, which contain immune-suppressive cells recruited by the CXCL13/CXCR5 axis, with or without TLSs, have not been fully illuminated. In addition, CXCL13-expressing CD8 ${ }^{+} \mathrm{T}$ 
cells are linked to the proinflammatory features of macrophages and show enhanced cytotoxicity following anti-PD-L1 therapy in triple-negative breast cancer [198]. Thus, better recognition of the specific microstructures in the TME might allow for the development of optimal treatment strategies. Additionally, understanding whether CXCL13/CXCR5 signaling could be an untapped target for inducing the recruitment of $\mathrm{B}$ cells and the formation of TLSs in the TME could complement current immunotherapy.

Author Contributions: S.-H.G.: writing, review, and editing. S.-Z.L.: writing, review and editing. G.-Z.W.: review and editing. G.-B.Z.: writing, review, and editing. All authors have read and agreed to the published version of the manuscript.

Funding: This work was jointly supported by the National Key Research and Development Program of China (No. 2020YFA0803300), the Key Project of the National Natural Science Foundation of China (81830093), the CAMS Innovation Fund for Medical Sciences (CIFMS; 2021-RC310-003, 2020-RC310002), CAMS Initiative for Innovative Medicine (2021-1-I2M-012), and the National Natural Science Foundation of China (81672765, 81802796, and 82073092).

Institutional Review Board Statement: Not applicable.

Informed Consent Statement: Not applicable.

Conflicts of Interest: The authors declare no conflict of interest.

\section{References}

1. Albert Zlotnik, O.Y. Chemokines: A New Classification System and Their Role in Immunity. Immunity 2000, 12, 121-127. [CrossRef]

2. Murdoch, C.; Finn, A. Chemokine receptors and their role in inflammation and infectious diseases. Am. Soc. Hematol. 2000, 95, 3032-3043.

3. Ziarek, J.J.; Kleist, A.B.; London, N.; Raveh, B.; Montpas, N.; Bonneterre, J.; St-Onge, G.; DiCosmo-Ponticello, C.J.; Koplinski, C.A.; Roy, I.; et al. Structural basis for chemokine recognition by a $\mathrm{G}$ protein-coupled receptor and implications for receptor activation. Sci. Signal. 2017, 10, 471. [CrossRef]

4. Nagarsheth, N.; Wicha, M.S.; Zou, W. Chemokines in the cancer microenvironment and their relevance in cancer immunotherapy. Nat. Rev. Immunol. 2017, 17, 559-572. [CrossRef]

5. Lacalle, R.A.; Blanco, R.; Carmona-Rodriguez, L.; Martin-Leal, A.; Mira, E.; Manes, S. Chemokine Receptor Signaling and the Hallmarks of Cancer. Int. Rev. Cell Mol. Biol. 2017, 331, 181-244.

6. Lazennec, G.; Richmond, A. Chemokines and chemokine receptors: New insights into cancer-related inflammation. Trends Mol. Med. 2010, 16, 133-144. [CrossRef] [PubMed]

7. Raman, D.; Baugher, P.J.; Thu, Y.M.; Richmond, A. Role of chemokines in tumor growth. Cancer Lett. 2007, 256, 137-165. [CrossRef] [PubMed]

8. Belperio, J.A.; Keane, M.P.; Arenberg, D.A.; Addison, C.L.; Ehlert, J.E.; Burdick, M.D.; Strieter, R.M. CXC chemokines in angiogenesis. J. Leukoc Biol. 2000, 68, 1-8.

9. Garon, E.B.; Rizvi, N.A.; Hui, R.; Leighl, N.; Balmanoukian, A.S.; Eder, J.P.; Patnaik, A.; Aggarwal, C.; Gubens, M.; Horn, L.; et al. Pembrolizumab for the treatment of non-small-cell lung cancer. N. Engl. J. Med. 2015, 372, 2018-2028. [CrossRef] [PubMed]

10. Snyder, A.; Makarov, V.; Merghoub, T.; Yuan, J.; Zaretsky, J.M.; Desrichard, A.; Walsh, L.A.; Postow, M.A.; Wong, P.; Ho, T.S.; et al. Genetic basis for clinical response to CTLA-4 blockade in melanoma. N. Engl. J. Med. 2014, 371, 2189-2199. [CrossRef]

11. D'Alterio, C.; Buoncervello, M.; Ierano, C.; Napolitano, M.; Portella, L.; Rea, G.; Barbieri, A.; Luciano, A.; Scognamiglio, G.; Tatangelo, F.; et al. Targeting CXCR4 potentiates anti-PD-1 efficacy modifying the tumor microenvironment and inhibiting neoplastic PD-1. J. Exp. Clin. Cancer Res. 2019, 38, 432. [CrossRef] [PubMed]

12. Highfill, S.L.; Cui, Y.; Giles, A.J.; Smith, J.P.; Zhang, H.; Morse, E.; Kaplan, R.N.; Mackall, C.L. Disruption of CXCR2-mediated MDSC tumor trafficking enhances anti-PD1 efficacy. Sci. Transl. Med. 2014, 6, 237ra67. [CrossRef] [PubMed]

13. Gunn, M.D.; Ngo, V.N.; Ansel, K.M.; Ekland, E.H.; Cyster, J.G.; Williams, L.T. A B-cell-homing chemokine made in lymphoid follicles activates Burkitt's lymphoma receptor-1. Nature 1998, 391, 799-803. [CrossRef] [PubMed]

14. Galamb, O.; Gyõrffy, B.; Sipos, F.; Dinya, E.; Krenács, T.; Berczi, L.; Szõke, D.; Spisák, S.; Solymosi, N.; Németh, A.M.; et al. Helicobacter pylori and antrum erosion-specific gene expression patterns: The discriminative role of CXCL13 and VCAM1 transcripts. Helicobacter 2008, 13, 112-126. [CrossRef] [PubMed]

15. Shi, W.; Yang, B.; Sun, Q.; Meng, J.; Zhao, X.; Du, S.; Li, X.; Jiao, S. PD-1 regulates CXCR5(+) CD4 T cell-mediated proinflammatory functions in non-small cell lung cancer patients. Int. Immunopharmacol. 2020, 82, 106295. [CrossRef]

16. Cha, Z.; Qian, G.; Zang, Y.; Gu, H.; Huang, Y.; Zhu, L.; Li, J.; Liu, Y.; Tu, X.; Song, H.; et al. Circulating CXCR5+CD4+ T cells assist in the survival and growth of primary diffuse large B cell lymphoma cells through interleukin 10 pathway. Exp. Cell Res. 2017, 350, 154-160. [CrossRef] 
17. Pimenta, E.M.; De, S.; Weiss, R.; Feng, D.; Hall, K.; Kilic, S.; Bhanot, G.; Ganesan, S.; Ran, S.; Barnes, B.J. IRF5 is a novel regulator of CXCL13 expression in breast cancer that regulates CXCR5(+) B- and T-cell trafficking to tumor-conditioned media. Immunol. Cell Biol. 2015, 93, 486-499. [CrossRef]

18. Wang, G.Z.; Cheng, X.; Zhou, B.; Wen, Z.S.; Huang, Y.C.; Chen, H.B.; Li, G.F.; Huang, Z.L.; Zhou, Y.C.; Feng, L.; et al. The chemokine CXCL13 in lung cancers associated with environmental polycyclic aromatic hydrocarbons pollution. Elife 2015, 4, e09419. [CrossRef]

19. Renaudin, X.; Guervilly, J.H.; Aoufouchi, S.; Rosselli, F. Proteomic analysis reveals a FANCA-modulated neddylation pathway involved in CXCR5 membrane targeting and cell mobility. J. Cell Sci. 2014, 127, 3546-3554.

20. El-Haibi, C.P.; Sharma, P.; Singh, R.; Gupta, P.; Taub, D.D.; Singh, S.; Lillard, J.W., Jr. Differential G protein subunit expression by prostate cancer cells and their interaction with CXCR5. Mol. Cancer 2013, 12, 64. [CrossRef]

21. MacDonald, R.J.; Yen, A. CXCR5 overexpression in HL-60 cells enhances chemotaxis toward CXCL13 without anticipated interaction partners or enhanced MAPK signaling. Vitr. Cell Dev. Biol. Anim. 2018, 54, 725-735. [CrossRef] [PubMed]

22. Barroso, R.; Martinez Munoz, L.; Barrondo, S.; Vega, B.; Holgado, B.L.; Lucas, P.; Baillo, A.; Salles, J.; Rodriguez-Frade, J.M.; Mellado, M. EBI2 regulates CXCL13-mediated responses by heterodimerization with CXCR5. FASEB J. 2012, 26, $4841-4854$. [CrossRef]

23. Bookout, A.L.; Finney, A.E.; Guo, R.; Peppel, K.; Koch, W.J.; Daaka, Y. Targeting Gbetagamma signaling to inhibit prostate tumor formation and growth. J. Biol. Chem. 2003, 278, 37569-37573. [CrossRef]

24. Müller, G.; Lipp, M. Signal Transduction by the Chemokine Receptor CXCR5: Structural Requirements for G Protein Activation Analyzed by Chimeric CXCR1/CXCR5 Molecules. Biol. Chem. 2001, 382, 9. [CrossRef]

25. Dobner, T.; Wolf, I.; Emrich, T.; Lipp, M. Differentiation-specific expression of a novel G protein-coupled receptor from Burkitt's lymphoma. Eur. J. Immunol. 1992, 22, 2795-2799. [CrossRef]

26. Ansel, K.M.; Ngo, V.N.; Hyman, P.L.; Luther, S.A.; Forster, R.; Sedgwick, J.D.; Browning, J.L.; Lipp, M.; Cyster, J.G. A chemokinedriven positive feedback loop organizes lymphoid follicles. Nature 2000, 406, 309-314. [CrossRef] [PubMed]

27. Legler, D.F.; Loetscher, M.; Roos, R.S.; Clark-Lewis, I.; Baggiolini, M.; Moser, B. B cell-attracting chemokine 1, a human CXC chemokine expressed in lymphoid tissues, selectively attracts B lymphocytes via BLR1/CXCR5. J. Exp. Med. 1998, 187, 655-660. [CrossRef] [PubMed]

28. Mueller, S.N.; Germain, R.N. Stromal cell contributions to the homeostasis and functionality of the immune system. Nat. Rev. Immunol. 2009, 9, 618-629. [CrossRef] [PubMed]

29. Kaiser, E.; Forster, R.; Wolf, I.; Ebensperger, C.; Kuehl, W.M.; Lipp, M. The G protein-coupled receptor BLR1 is involved in murine $\mathrm{B}$ cell differentiation and is also expressed in neuronal tissues. Eur. J. Immunol. 1993, 23, 2532-2539. [CrossRef]

30. Breitfeld, D.; Ohl, L.; Kremmer, E.; Ellwart, J.; Sallusto, F.; Lipp, M.; Forster, R. Follicular B helper T cells express CXC chemokine receptor 5, localize to B cell follicles, and support immunoglobulin production. J. Exp. Med. 2000, 192, 1545-1552. [CrossRef]

31. Schaerli, P.; Willimann, K.; Lang, A.B.; Lipp, M.; Loetscher, P.; Moser, B. CXC chemokine receptor 5 expression defines follicular homing T cells with B cell helper function. J. Exp. Med. 2000, 192, 1553-1562. [CrossRef] [PubMed]

32. Leon, B.; Ballesteros-Tato, A.; Browning, J.L.; Dunn, R.; Randall, T.D.; Lund, F.E. Regulation of T(H)2 development by CXCR5+ dendritic cells and lymphotoxin-expressing B cells. Nat. Immunol. 2012, 13, 681-690. [CrossRef] [PubMed]

33. Saeki, H.; Wu, M.; Olasz, E.; Hwang, S.T. A migratory population of skin-derived dendritic cells expresses CXCR5, responds to B lymphocyte chemoattractant in vitro, and co-localizes to B cell zones in lymph nodes in vivo. Eur. J. Immunol. 2000, 30, 2808-2814. [CrossRef]

34. Forster, R.; Mattis, A.E.; Kremmer, E.; Wolf, E.; Brem, G.; Lipp, M. A Putative Chemokine Receptor, BLR1, Directs B Cell Migration to Defined Lymphoid Organs and Specific Anatomic Compartments of the Spleen. Cell 1996, 87, 1037-1047. [CrossRef]

35. Muller, G.; Hopken, U.E.; Lipp, M. The impact of CCR7 and CXCR5 on lymphoid organ development and systemic immunity. Immunol. Rev. 2003, 195, 117-135. [CrossRef]

36. Carlsen, H.S.; Baekkevold, E.S.; Johansen, F.E.; Haraldsen, G.; Brandtzaeg, P. B cell attracting chemokine 1 (CXCL13) and its receptor CXCR5 are expressed in normal and aberrant gut associated lymphoid tissue. Gut 2002, 51, 364-371. [CrossRef]

37. Saez de Guinoa, J.; Barrio, L.; Mellado, M.; Carrasco, Y.R. CXCL13/CXCR5 signaling enhances BCR-triggered B-cell activation by shaping cell dynamics. Blood 2011, 118, 1560-1569. [CrossRef]

38. Tse, K.W.; Lin, K.B.; Dang-Lawson, M.; Guzman-Perez, A.; Aspnes, G.E.; Buckbinder, L.; Gold, M.R. Small molecule inhibitors of the Pyk 2 and FAK kinases modulate chemoattractant-induced migration, adhesion and Akt activation in follicular and marginal zone B cells. Cell Immunol. 2012, 275, 47-54. [CrossRef]

39. Kim, S.H.; Kim, Y.N.; Jang, Y.S. Cutting Edge: LL-37-Mediated Formyl Peptide Receptor-2 Signaling in Follicular Dendritic Cells Contributes to B Cell Activation in Peyer's Patch Germinal Centers. J. Immunol. 2017, 198, 629-633. [CrossRef]

40. Ise, W.; Fujii, K.; Shiroguchi, K.; Ito, A.; Kometani, K.; Takeda, K.; Kawakami, E.; Yamashita, K.; Suzuki, K.; Okada, T.; et al. T Follicular Helper Cell-Germinal Center B Cell Interaction Strength Regulates Entry into Plasma Cell or Recycling Germinal Center Cell Fate. Immunity 2018, 48, 702-715.e4. [CrossRef]

41. Gao, X.; Lin, L.; Yu, D. Ex Vivo Culture Assay to Measure Human Follicular Helper T (Tfh) Cell-Mediated Human B Cell Proliferation and Differentiation. Methods Mol. Biol. 2018, 111-119. 
42. Havenar-Daughton, C.; Lindqvist, M.; Heit, A.; Wu, J.E.; Reiss, S.M.; Kendric, K.; Belanger, S.; Kasturi, S.P.; Landais, E.; Akondy, R.S.; et al. CXCL13 is a plasma biomarker of germinal center activity. Proc. Natl. Acad. Sci. USA 2016, 113, $2702-2707$. [CrossRef]

43. Broker, K.; Figge, J.; Magnusen, A.F.; Manz, R.A.; Kohl, J.; Karsten, C.M. A Novel Role for C5a in B-1 Cell Homeostasis. Front. Immunol. 2018, 9, 258. [CrossRef]

44. Ansel, K.M.; Harris, R.B.S.; Cyster, J.G. CXCL13 Is Required for B1 Cell Homing, Natural Antibody Production, and Body Cavity Immunity. Immunity 2002, 16, 67-76. [CrossRef]

45. Bracke, K.R.; Verhamme, F.M.; Seys, L.J.; Bantsimba-Malanda, C.; Cunoosamy, D.M.; Herbst, R.; Hammad, H.; Lambrecht, B.N.; Joos, G.F.; Brusselle, G.G. Role of CXCL13 in cigarette smoke-induced lymphoid follicle formation and chronic obstructive pulmonary disease. Am. J. Respir. Crit. Care Med. 2013, 188, 343-355. [CrossRef] [PubMed]

46. Bombardieri, M.; Lewis, M.; Pitzalis, C. Ectopic lymphoid neogenesis in rheumatic autoimmune diseases. Nat. Rev. Rheumatol. 2017, 13, 141-154. [CrossRef]

47. Eddens, T.; Elsegeiny, W.; Garcia-Hernadez, M.L.; Castillo, P.; Trevejo-Nunez, G.; Serody, K.; Campfield, B.T.; Khader, S.A.; Chen, K.; Rangel-Moreno, J.; et al. Pneumocystis-Driven Inducible Bronchus-Associated Lymphoid Tissue Formation Requires Th2 and Th17 Immunity. Cell Rep. 2017, 18, 3078-3090. [CrossRef] [PubMed]

48. Mueller, C.G.; Nayar, S.; Gardner, D.; Barone, F. Cellular and Vascular Components of Tertiary Lymphoid Structures. Methods Mol. Biol. 2018, 1845, 17-30. [PubMed]

49. Wang, S.S.; Liu, W.; Ly, D.; Xu, H.; Qu, L.; Zhang, L. Tumor-infiltrating B cells: Their role and application in anti-tumor immunity in lung cancer. Cell Mol. Immunol. 2019, 16, 6-18. [CrossRef]

50. Yu, Q.; Cheng, Y.; Wang, Y.; Wang, C.; Lu, H.; Guan, Z.; Huang, J.; Gong, W.; Shi, M.; Ni, L.; et al. Aberrant Humoral Immune Responses in Neurosyphilis: CXCL13/CXCR5 Play a Pivotal Role for B-Cell Recruitment to the Cerebrospinal Fluid. J. Infect. Dis. 2017, 216, 534-544. [CrossRef] [PubMed]

51. Cabrita, R.; Lauss, M.; Sanna, A.; Donia, M.; Skaarup Larsen, M.; Mitra, S.; Johansson, I.; Phung, B.; Harbst, K.; VallonChristersson, J.; et al. Tertiary lymphoid structures improve immunotherapy and survival in melanoma. Nature 2020, 577, 561-565. [CrossRef] [PubMed]

52. Da, Z.; Li, L.; Zhu, J.; Gu, Z.; You, B.; Shan, Y.; Shi, S. CXCL13 Promotes Proliferation of Mesangial Cells by Combination with CXCR5 in SLE. J. Immunol. Res. 2016, 2016, 2063985. [CrossRef] [PubMed]

53. Meraouna, A.; Cizeron-Clairac, G.; Panse, R.L.; Bismuth, J.; Truffault, F.; Tallaksen, C.; Berrih-Aknin, S. The chemokine CXCL13 is a key molecule in autoimmune myasthenia gravis. Blood 2006, 108, 432-440. [CrossRef] [PubMed]

54. Silina, K.; Soltermann, A.; Attar, F.M.; Casanova, R.; Uckeley, Z.M.; Thut, H.; Wandres, M.; Isajevs, S.; Cheng, P.; CurioniFontecedro, A.; et al. Germinal Centers Determine the Prognostic Relevance of Tertiary Lymphoid Structures and Are Impaired by Corticosteroids in Lung Squamous Cell Carcinoma. Cancer Res. 2018, 78, 1308-1320. [CrossRef]

55. Denton, A.E.; Innocentin, S.; Carr, E.J.; Bradford, B.M.; Lafouresse, F.; Mabbott, N.A.; Mörbe, U.; Ludewig, B.; Groom, J.R.; Good-Jacobson, K.L.; et al. Type I interferon induces CXCL13 to support ectopic germinal center formation. J. Exp. Med. 2019, 216, 621-637. [CrossRef] [PubMed]

56. Bellamri, N.; Viel, R.; Morzadec, C.; Lecureur, V.; Joannes, A.; de Latour, B.; Llamas-Gutierrez, F.; Wollin, L.; Jouneau, S.; Vernhet, L. TNF- $\alpha$ and IL-10 Control CXCL13 Expression in Human Macrophages. J. Immunol. 2020, 204, 2492-2502. [CrossRef]

57. Yoshitomi, H. CXCL13-producing PD-1(hi)CXCR5(-) helper T cells in chronic inflammation. Immunol. Med. 2020, 43, 156-160. [CrossRef]

58. Bransfield, R.C. The psychoimmunology of lyme/tick-borne diseases and its association with neuropsychiatric symptoms. Open Neurol. 2012, 6, 88-93. [CrossRef]

59. Traianos, E.Y.; Locke, J.; Lendrem, D.; Bowman, S.; Hargreaves, B.; Macrae, V.; Tarn, J.R.; Ng, W.-F. Serum CXCL13 levels are associated with lymphoma risk and lymphoma occurrence in primary Sjögren's syndrome. Rheumatol. Int. 2020, 40, 541-548. [CrossRef]

60. Colafrancesco, S.; Priori, R.; Smith, C.G.; Minniti, A.; Iannizzotto, V.; Pipi, E.; Lucchesi, D.; Pontarini, E.; Nayar, S.; Campos, J.; et al. CXCL13 as biomarker for histological involvement in Sjogren's syndrome. Rheumatology 2020, 59, 165-170. [CrossRef]

61. Shiao, Y.M.; Lee, C.C.; Hsu, Y.H.; Huang, S.F.; Lin, C.Y.; Li, L.H.; Fann, C.S.; Tsai, C.Y.; Tsai, S.F.; Chiu, H.C. Ectopic and high CXCL13 chemokine expression in myasthenia gravis with thymic lymphoid hyperplasia. J. Neuroimmunol. 2010, 221, 101-106. [CrossRef] [PubMed]

62. van der Vorst, E.P.C.; Daissormont, I.; Aslani, M.; Seijkens, T.; Wijnands, E.; Lutgens, E.; Duchene, J.; Santovito, D.; Döring, Y.; Halvorsen, B.; et al. Interruption of the CXCL13/CXCR5 Chemokine Axis Enhances Plasma IgM Levels and Attenuates Atherosclerosis Development. Thromb. Haemost. 2019, 120, 344-347. [CrossRef] [PubMed]

63. Bao, Y.-Q.; Wang, J.-P.; Dai, Z.-W.; Mao, Y.-M.; Wu, J.; Guo, H.-S.; Xia, Y.-R.; Ye, D.-Q. Increased circulating CXCL13 levels in systemic lupus erythematosus and rheumatoid arthritis: A meta-analysis. Clin. Rheumatol. 2019, 39, 281-290. [CrossRef]

64. Rupprecht, T.A.; Manz, K.M.; Fingerle, V.; Lechner, C.; Klein, M.; Pfirrmann, M.; Koedel, U. Diagnostic value of cerebrospinal fluid CXCL13 for acute Lyme neuroborreliosis. A systematic review and meta-analysis. Clin. Microbiol. Infect. 2018, 24, 1234-1240. [CrossRef] [PubMed] 
65. Kusuyama, J.; Bandow, K.; Ohnishi, T.; Amir, M.S.; Shima, K.; Semba, I.; Matsuguchi, T. CXCL13 is a differentiation- and hypoxia-induced adipocytokine that exacerbates the inflammatory phenotype of adipocytes through PHLPP1 induction. Biochem. J. 2019, 476, 3533-3548. [CrossRef]

66. Liu, S.; Liu, X.; Xiong, H.; Wang, W.; Liu, Y.; Yin, L.; Tu, C.; Wang, H.; Xiang, X.; Xu, J.; et al. CXCL13/CXCR5 signaling contributes to diabetes-induced tactile allodynia via activating pERK, pSTAT3, pAKT pathways and pro-inflammatory cytokines production in the spinal cord of male mice. Brain Behav. Immun. 2019, 80, 711-724. [CrossRef]

67. Zhang, G.; Ducatelle, R.; De Bruyne, E.; Joosten, M.; Bosschem, I.; Smet, A.; Haesebrouck, F.; Flahou, B. Role of $\gamma-$ glutamyltranspeptidase in the pathogenesis of Helicobacter suis and Helicobacter pylori infections. Vet. Res. 2015, 46, 31. [CrossRef]

68. Mazzucchelli, L.; Blaser, A.; Kappeler, A.; Scharli, P.; Laissue, J.A.; Baggiolini, M.; Uguccioni, M. BCA-1 is highly expressed in Helicobacter pylori-induced mucosa-associated lymphoid tissue and gastric lymphoma. J. Clin. Investig. 1999, 104, R49-R54. [CrossRef]

69. Yamamoto, K.; Nishiumi, S.; Yang, L.; Klimatcheva, E.; Pandina, T.; Takahashi, S.; Matsui, H.; Nakamura, M.; Zauderer, M.; Yoshida, M.; et al. Anti-CXCL13 antibody can inhibit the formation of gastric lymphoid follicles induced by Helicobacter infection. Mucosal. Immunol. 2014, 7, 1244-1254. [CrossRef]

70. Sahini, N.; Borlak, J. Genomics of human fatty liver disease reveal mechanistically linked lipid droplet-associated gene regulations in bland steatosis and nonalcoholic steatohepatitis. Transl. Res. 2016, 177, 41-69. [CrossRef]

71. Jiang, B.C.; Cao, D.L.; Zhang, X.; Zhang, Z.J.; He, L.N.; Li, C.H.; Zhang, W.W.; Wu, X.B.; Berta, T.; Ji, R.R.; et al. CXCL13 drives spinal astrocyte activation and neuropathic pain via CXCR5. J. Clin. Investig. 2016, 126, 745-761. [CrossRef]

72. Trolese, M.C.; Mariani, A.; Terao, M.; de Paola, M.; Fabbrizio, P.; Sironi, F.; Kurosaki, M.; Bonanno, S.; Marcuzzo, S.; Bernasconi, P.; et al. CXCL13/CXCR5 signalling is pivotal to preserve motor neurons in amyotrophic lateral sclerosis. EBioMedicine 2020, $62,103097$. [CrossRef] [PubMed]

73. El-Haibi, C.P.; Singh, R.; Gupta, P.; Sharma, P.K.; Greenleaf, K.N.; Singh, S.; Lillard, J.W., Jr. Antibody Microarray Analysis of Signaling Networks Regulated by Cxcl13 and Cxcr5 in Prostate Cancer. J. Proteom. Bioinform. 2012, 5, 177-184. [CrossRef] [PubMed]

74. Yuvaraj, S.; Griffin, A.C.; Sundaram, K.; Kirkwood, K.L.; Norris, J.S.; Reddy, S.V. A novel function of CXCL13 to stimulate RANK ligand expression in oral squamous cell carcinoma cells. Mol. Cancer Res. 2009, 7, 1399-1407. [CrossRef] [PubMed]

75. Cha, Z.; Gu, H.; Zang, Y.; Wang, Z.; Li, J.; Huang, W.; Qin, A.; Zhu, L.; Tu, X.; Cheng, N.; et al. The prevalence and function of CD4(+)CXCR5(+)Foxp3(+) follicular regulatory T cells in diffuse large B cell lymphoma. Int. Immunopharmacol. 2018, 61, 132-139. [CrossRef]

76. Meng, X.; Yu, X.; Dong, Q.; Xu, X.; Li, J.; Xu, Q.; Ma, J.; Zhou, C. Distribution of circulating follicular helper T cells and expression of interleukin-21 and chemokine C-X-C ligand 13 in gastric cancer. Oncol. Lett. 2018, 16, 3917-3922. [CrossRef]

77. Ohandjo, A.Q.; Liu, Z.; Dammer, E.B.; Dill, C.D.; Griffen, T.L.; Carey, K.M.; Hinton, D.E.; Meller, R.; Lillard, J.W., Jr. Transcriptome Network Analysis Identifies CXCL13-CXCR5 Signaling Modules in the Prostate Tumor Immune Microenvironment. Sci. Rep. 2019, 9, 14963. [CrossRef]

78. Hussain, M.; Liu, J.; Wang, G.Z.; Zhou, G.B. CXCL13 Signaling in the Tumor Microenvironment. Adv. Exp. Med. Biol. 2021, 1302, 71-90.

79. Goswami, S.; Chen, Y.; Anandhan, S.; Szabo, P.M.; Basu, S.; Blando, J.M.; Liu, W.; Zhang, J.; Natarajan, S.M.; Xiong, L.; et al. ARID1A mutation plus CXCL13 expression act as combinatorial biomarkers to predict responses to immune checkpoint therapy in mUCC. Sci. Transl. Med. 2020, 12, 548. [CrossRef]

80. Im, S.J.; Hashimoto, M.; Gerner, M.Y.; Lee, J.; Kissick, H.T.; Burger, M.C.; Shan, Q.; Hale, J.S.; Lee, J.; Nasti, T.H.; et al. Defining CD8+ T cells that provide the proliferative burst after PD-1 therapy. Nature 2016, 537, 417-421. [CrossRef]

81. He, R.; Hou, S.; Liu, C.; Zhang, A.; Bai, Q.; Han, M.; Yang, Y.; Wei, G.; Shen, T.; Yang, X.; et al. Follicular CXCR5- expressing CD8(+) T cells curtail chronic viral infection. Nature 2016, 537, 412-428. [CrossRef] [PubMed]

82. Tian, F.; Ji, X.L.; Xiao, W.A.; Wang, B.; Wang, F. CXCL13 Promotes Osteogenic Differentiation of Mesenchymal Stem Cells by Inhibiting miR-23a Expression. Stem. Cells Int. 2015, 2015, 632305. [CrossRef] [PubMed]

83. Biswas, S.; Sengupta, S.; Roy Chowdhury, S.; Jana, S.; Mandal, G.; Mandal, P.K.; Saha, N.; Malhotra, V.; Gupta, A.; Kuprash, D.V.; et al. CXCL13-CXCR5 co-expression regulates epithelial to mesenchymal transition of breast cancer cells during lymph node metastasis. Breast Cancer Res. Treat. 2014, 143, 265-276. [CrossRef]

84. Sambandam, Y.; Sundaram, K.; Liu, A.; Kirkwood, K.L.; Ries, W.L.; Reddy, S.V. CXCL13 activation of c-Myc induces RANK ligand expression in stromal/preosteoblast cells in the oral squamous cell carcinoma tumor-bone microenvironment. Oncogene 2013, 32, 97-105. [CrossRef] [PubMed]

85. Ohtani, H.; Komeno, T.; Agatsuma, Y.; Kobayashi, M.; Noguchi, M.; Nakamura, N. Follicular Dendritic Cell Meshwork in Angioimmunoblastic T-Cell Lymphoma Is Characterized by Accumulation of CXCL13(+) Cells. J. Clin. Exp. Hematop. 2015, 55, 61-69. [CrossRef]

86. Heinig, K.; Gatjen, M.; Grau, M.; Stache, V.; Anagnostopoulos, I.; Gerlach, K.; Niesner, R.A.; Cseresnyes, Z.; Hauser, A.E.; Lenz, P.; et al. Access to follicular dendritic cells is a pivotal step in murine chronic lymphocytic leukemia B-cell activation and proliferation. Cancer Discov. 2014, 4, 1448-1465. [CrossRef] 
87. Ammirante, M.; Shalapour, S.; Kang, Y.; Jamieson, C.A.; Karin, M. Tissue injury and hypoxia promote malignant progression of prostate cancer by inducing CXCL13 expression in tumor myofibroblasts. Proc. Natl. Acad. Sci. USA 2014, 111, 14776-14781. [CrossRef]

88. Singh, S.; Singh, R.; Sharma, P.K.; Singh, U.P.; Rai, S.N.; Chung, L.W.K.; Cooper, C.R.; Novakovic, K.R.; Grizzle, W.E.; Lillard, J.W. Serum CXCL13 positively correlates with prostatic disease, prostate-specific antigen and mediates prostate cancer cell invasion, integrin clustering and cell adhesion. Cancer Lett. 2009, 283, 29-35. [CrossRef]

89. Gu-Trantien, C.; Migliori, E.; Buisseret, L.; de Wind, A.; Brohee, S.; Garaud, S.; Noel, G.; Dang Chi, V.L.; Lodewyckx, J.N.; Naveaux, C.; et al. CXCL13-producing TFH cells link immune suppression and adaptive memory in human breast cancer. JCI Insight 2017, 2, 11. [CrossRef]

90. Thommen, D.S.; Koelzer, V.H.; Herzig, P.; Roller, A.; Trefny, M.; Dimeloe, S.; Kiialainen, A.; Hanhart, J.; Schill, C.; Hess, C.; et al. A transcriptionally and functionally distinct PD-1(+) CD8(+) T cell pool with predictive potential in non-small-cell lung cancer treated with PD-1 blockade. Nat. Med. 2018, 24, 994-1004. [CrossRef] [PubMed]

91. Workel, H.H.; Lubbers, J.M.; Arnold, R.; Prins, T.M.; van der Vlies, P.; de Lange, K.; Bosse, T.; van Gool, I.C.; Eggink, F.A.; Wouters, M.C.A.; et al. A Transcriptionally Distinct CXCL13(+)CD103(+)CD8(+) T-cell Population Is Associated with B-cell Recruitment and Neoantigen Load in Human Cancer. Cancer Immunol. Res. 2019, 7, 784-796. [CrossRef]

92. Zhou, G. Tobacco, air pollution, environmental carcinogenesis, and thoughts on conquering strategies of lung cancer. Cancer Biol. Med. 2019, 16, 700 .

93. Centers for Disease Control and Prevention (US); National Center for Chronic Disease Prevention and Health Promotion (US); Office on Smoking and Health (US). How Tobacco Smoke Causes Disease: The Biology and Behavioral Basis for Smoking-Attributable Disease: A Report of the Surgeon General; Centers for Disease Control and Prevention (US): Atlanta, GA, USA, 2010. Available online: http:/ / www.ncbi.nlm.nih.gov/books/NBK53017/ (accessed on 2 September 2021).

94. Shiels, M.S.; Pfeiffer, R.M.; Hildesheim, A.; Engels, E.A.; Kemp, T.J.; Park, J.-H.; Katki, H.A.; Koshiol, J.; Shelton, G.; Caporaso, N.E.; et al. Inflammation Markers and Prospective Risk for Lung Cancer. J. Natl. Cancer Inst. 2013, 105, 1871-1880. [CrossRef]

95. Zhao, Q.; Guo, J.; Wang, G.; Bi, Y.; Cheng, X.; Liao, Y.; Jin, S.; Li, L.; Guo, Y.; Pan, L.; et al. CXCL13 promotes intestinal tumorigenesis through the activation of epithelial AKT signaling. Cancer Lett. 2021, 511, 1-14. [CrossRef] [PubMed]

96. Kazanietz, M.G.; Durando, M.; Cooke, M. CXCL13 and Its Receptor CXCR5 in Cancer: Inflammation, Immune Response, and Beyond. Front. Endocrinol. 2019, 10, 471. [CrossRef]

97. Zheng, Z.; Cai, Y.; Chen, H.; Chen, Z.; Zhu, D.; Zhong, Q.; Xie, W. CXCL13/CXCR5 Axis Predicts Poor Prognosis and Promotes Progression Through PI3K/AKT/mTOR Pathway in Clear Cell Renal Cell Carcinoma. Front. Oncol. 2018, 8, 682. [CrossRef] [PubMed]

98. Zhu, Z.; Zhang, X.; Guo, H.; Fu, L.; Pan, G.; Sun, Y. CXCL13-CXCR5 axis promotes the growth and invasion of colon cancer cells via PI3K/AKT pathway. Mol. Cell Biochem. 2015, 400, 287-295. [CrossRef]

99. Meijer, J.; Zeelenberg, I.S.; Sipos, B.; Roos, E. The CXCR5 chemokine receptor is expressed by carcinoma cells and promotes growth of colon carcinoma in the liver. Cancer Res. 2006, 66, 9576-9582. [CrossRef] [PubMed]

100. El Haibi, C.P.; Sharma, P.K.; Singh, R.; Johnson, P.R.; Suttles, J.; Singh, S.; Lillard, J.W., Jr. PI3Kp110-, Src-, FAK-dependent and DOCK2-independent migration and invasion of CXCL13-stimulated prostate cancer cells. Mol. Cancer 2010, 9, 85. [CrossRef]

101. El-Haibi, C.P.; Singh, R.; Sharma, P.K.; Singh, S.; Lillard, J.W., Jr. CXCL13 mediates prostate cancer cell proliferation through JNK signalling and invasion through ERK activation. Cell Prolif. 2011, 44, 311-319. [CrossRef]

102. Xu, L.; Liang, Z.; Li, S.; Ma, J. Signaling via the CXCR5/ERK pathway is mediated by CXCL13 in mice with breast cancer. Oncol. Lett. 2018, 15, 9293-9298. [CrossRef] [PubMed]

103. Ticchioni, M.; Essafi, M.; Jeandel, P.Y.; Davi, F.; Cassuto, J.P.; Deckert, M.; Bernard, A. Homeostatic chemokines increase survival of B-chronic lymphocytic leukemia cells through inactivation of transcription factor FOXO3a. Oncogene 2007, 26, 7081-7091. [CrossRef] [PubMed]

104. Ma, J.J.; Jiang, L.; Tong, D.Y.; Ren, Y.N.; Sheng, M.F.; Liu, H.C. CXCL13 inhibition induce the apoptosis of MDA-MB-231 breast cancer cells through blocking CXCR5/ERK signaling pathway. Eur. Rev. Med. Pharmacol. Sci. 2018, 22, 8755-8762.

105. Hu, C.; Xiong, J.; Zhang, L.; Huang, B.; Zhang, Q.; Li, Q.; Yang, M.; Wu, Y.; Wu, Q.; Shen, Q.; et al. PEG10 activation by CXCR5 and CCR7 CD19+CD34+ B cells acute and chronic lymphocytic leukemia. Cell. Mol. Immunol. 2004, 1, 280-294. [PubMed]

106. Chunsong, H.; Yuling, H.; Li, W.; Jie, X.; Gang, Z.; Qiuping, Z.; Qingping, G.; Kejian, Z.; Li, Q.; Chang, A.E.; et al. CXC chemokine ligand 13 and $C C$ chemokine ligand 19 cooperatively render resistance to apoptosis in $\mathrm{B}$ cell lineage acute and chronic lymphocytic leukemia CD23+CD5+ B cells. J. Immunol. 2006, 177, 6713-6722. [CrossRef]

107. Huang, H.; Liu, Y.; Wang, L.; Li, W. Age-related macular degeneration phenotypes are associated with increased tumor necrosisalpha and subretinal immune cells in aged Cxcr5 knockout mice. PLoS ONE 2017, 12, e0173716. [CrossRef]

108. Wang, W.J.; Wang, H.; Wang, M.S.; Huang, Y.Q.; Ma, Y.Y.; Qi, J.; Shi, J.P.; Li, W. Assessing the prognostic value of stemness-related genes in breast cancer patients. Sci. Rep. 2020, 10, 18325. [CrossRef]

109. Sorrentino, C.; Ciummo, S.L.; Cipollone, G.; Caputo, S.; Bellone, M.; Di Carlo, E. Interleukin-30/IL27p28 Shapes Prostate Cancer Stem-like Cell Behavior and Is Critical for Tumor Onset and Metastasization. Cancer Res. 2018, 78, 2654-2668. [CrossRef] 
110. Shalapour, S.; Font-Burgada, J.; Di Caro, G.; Zhong, Z.; Sanchez-Lopez, E.; Dhar, D.; Willimsky, G.; Ammirante, M.; Strasner, A.; Hansel, D.E.; et al. Immunosuppressive plasma cells impede T-cell-dependent immunogenic chemotherapy. Nature 2015, 521, 94-98. [CrossRef]

111. Zhang, G.; Miao, F.; Xu, J.; Wang, R. Mesenchymal stem cells from bone marrow regulate invasion and drug resistance of multiple myeloma cells by secreting chemokine CXCL13. Bosn. J. Basic Med. Sci. 2019, 20, 209. [CrossRef]

112. Zhang, G.; Luo, X.; Zhang, W.; Chen, E.; Xu, J.; Wang, F.; Cao, G.; Ju, Z.; Jin, D.; Huang, X.; et al. CXCL-13 Regulates Resistance to 5-Fluorouracil in Colorectal Cancer. Cancer Res. Treat. 2020, 52, 622-633. [CrossRef] [PubMed]

113. Fornecker, L.M.; Muller, L.; Bertrand, F.; Paul, N.; Pichot, A.; Herbrecht, R.; Chenard, M.P.; Mauvieux, L.; Vallat, L.; Bahram, S.; et al. Multi-omics dataset to decipher the complexity of drug resistance in diffuse large B-cell lymphoma. Sci. Rep. 2019, 9, 895. [CrossRef] [PubMed]

114. Medina, D.J.; Goodell, L.; Glod, J.; Gélinas, C.; Rabson, A.B.; Strair, R.K. Mesenchymal stromal cells protect mantle cell lymphoma cells from spontaneous and drug-induced apoptosis through secretion of B-cell activating factor and activation of the canonical and non-canonical nuclear factor $\mathrm{\kappa B}$ pathways. Haematologica 2012, 97, 1255. [CrossRef]

115. Ammirante, M.; Luo, J.L.; Grivennikov, S.; Nedospasov, S.; Karin, M. B-cell-derived lymphotoxin promotes castration-resistant prostate cancer. Nature 2010, 464, 302-305. [CrossRef] [PubMed]

116. Pylayeva-Gupta, Y.; Das, S.; Handler, J.S.; Hajdu, C.H.; Coffre, M.; Koralov, S.B.; Bar-Sagi, D. IL35-Producing B Cells Promote the Development of Pancreatic Neoplasia. Cancer Discov. 2016, 6, 247-255. [CrossRef]

117. Takahashi, R.; Macchini, M.; Sunagawa, M.; Jiang, Z.; Tanaka, T.; Valenti, G.; Renz, B.W.; White, R.A.; Hayakawa, Y.; Westphalen, C.B.; et al. Interleukin-1beta-induced pancreatitis promotes pancreatic ductal adenocarcinoma via B lymphocytemediated immune suppression. Gut 2020, 70, 330-341.

118. Lee, K.E.; Spata, M.; Bayne, L.J.; Buza, E.L.; Durham, A.C.; Allman, D.; Vonderheide, R.H.; Simon, M.C. Hif1a Deletion Reveals Pro-Neoplastic Function of B Cells in Pancreatic Neoplasia. Cancer Discov. 2016, 6, 256-269. [CrossRef]

119. Chen, X.; Takemoto, Y.; Deng, H.; Middelhoff, M.; Friedman, R.A.; Chu, T.H.; Churchill, M.J.; Ma, Y.; Nagar, K.K.; Tailor, Y.H.; et al. Histidine decarboxylase (HDC)-expressing granulocytic myeloid cells induce and recruit Foxp3(+) regulatory $\mathrm{T}$ cells in murine colon cancer. Oncoimmunology 2017, 6, e1290034. [CrossRef]

120. Ding, Y.; Shen, J.; Zhang, G.; Chen, X.; Wu, J.; Chen, W. CD40 controls CXCR5-induced recruitment of myeloid-derived suppressor cells to gastric cancer. Oncotarget 2015, 6, 38901-38911. [CrossRef]

121. Gillard-Bocquet, M.; Caer, C.; Cagnard, N.; Crozet, L.; Perez, M.; Fridman, W.H.; Sautes-Fridman, C.; Cremer, I. Lung tumor microenvironment induces specific gene expression signature in intratumoral NK cells. Front. Immunol. 2013, 4, 19. [CrossRef]

122. Garg, R.; Blando, J.M.; Perez, C.J.; Abba, M.C.; Benavides, F.; Kazanietz, M.G. Protein Kinase C Epsilon Cooperates with PTEN Loss for Prostate Tumorigenesis through the CXCL13-CXCR5 Pathway. Cell Rep. 2017, 19, 375-388. [CrossRef]

123. Li, B.H.; Garstka, M.A.; Li, Z.F. Chemokines and their receptors promoting the recruitment of myeloid-derived suppressor cells into the tumor. Mol. Immunol. 2020, 117, 201-215. [CrossRef]

124. Jin, K.; Cao, Y.; Gu, Y.; Fang, H.; Fei, Y.; Wang, J.; Liua, X.; Lva, K.; Hea, X.; Xu, J.; et al. Poor clinical outcomes and immunoevasive contexture in CXCL13+CD8+ T cells enriched gastric cancer patients. Oncoimmunology 2021, 10, 1915560. [CrossRef]

125. Keeley, E.C.; Mehrad, B.; Strieter, R.M. CXC chemokines in cancer angiogenesis and metastases. Adv. Cancer Res. 2010, 106, 91-111. [PubMed]

126. Spinetti, G.; Camarda, G.; Bernardini, G.; Romano Di Peppe, S.; Capogrossi, M.C.; Napolitano, M. The Chemokine CXCL13 (BCA-1) Inhibits FGF-2 Effects on Endothelial Cells. Biochem. Biophys. Res. Commun. 2001, 289, 19-24. [CrossRef] [PubMed]

127. Tsai, C.H.; Chen, C.J.; Gong, C.L.; Liu, S.C.; Chen, P.C.; Huang, C.C.; Hu, S.L.; Wang, S.W.; Tang, C.H. CXCL13/CXCR5 axis facilitates endothelial progenitor cell homing and angiogenesis during rheumatoid arthritis progression. Cell Death Disease 2021, 12, 846. [CrossRef] [PubMed]

128. Nagai, M.; Noguchi, R.; Takahashi, D.; Morikawa, T.; Koshida, K.; Komiyama, S.; Ishihara, N.; Yamada, T.; Kawamura, Y.I.; Muroi, K.; et al. Fasting-Refeeding Impacts Immune Cell Dynamics and Mucosal Immune Responses. Cell 2019, 178, 1072-1087.e14. [CrossRef] [PubMed]

129. Jordan, S.; Tung, N.; Casanova-Acebes, M.; Chang, C.; Cantoni, C.; Zhang, D.; Wirtz, T.H.; Naik, S.; Rose, S.A.; Brocker, C.N.; et al. Dietary Intake Regulates the Circulating Inflammatory Monocyte Pool. Cell 2019, 178, 1102-1114. [CrossRef]

130. Zhang, L.; Teng, Y.; Zhang, Y.; Liu, J.; Xu, L.; Qu, J.; Hou, K.; Yang, X.; Liu, Y.; Qu, X. C-Src-mediated RANKL-induced breast cancer cell migration by activation of the ERK and Akt pathway. Oncol Lett. 2012, 3, 395-400. [CrossRef]

131. Irshad, S.; Flores-Borja, F.; Lawler, K.; Monypenny, J.; Evans, R.; Male, V.; Gordon, P.; Cheung, A.; Gazinska, P.; Noor, F.; et al. RORgammat(+) Innate Lymphoid Cells Promote Lymph Node Metastasis of Breast Cancers. Cancer Res. 2017, 77, $1083-1096$. [CrossRef]

132. Yan, Q.; Yuan, Y.; Yankui, L.; Jingjie, F.; Linfang, J.; Yong, P.; Dong, H.; Xiaowei, Q. The Expression and Significance of CXCR5 and MMP-13 in Colorectal Cancer. Cell Biochem. Biophys. 2015, 73, 253-259. [CrossRef] [PubMed]

133. Zhao, S.; Mi, Y.; Guan, B.; Zheng, B.; Wei, P.; Gu, Y.; Zhang, Z.; Cai, S.; Xu, Y.; Li, X.; et al. Tumor-derived exosomal miR-934 induces macrophage M2 polarization to promote liver metastasis of colorectal cancer. J. Hematol. Oncol. 2020, 13, 156. [CrossRef]

134. Baeuerle, P.A.; Henkel, T. Function and activation of NF-kappa B in the immune system. Annu. Rev. Immunol. 1994, 12, 141-179. [CrossRef] [PubMed] 
135. Biswas, S.; Roy Chowdhury, S.; Mandal, G.; Purohit, S.; Gupta, A.; Bhattacharyya, A. RelA driven co-expression of CXCL13 and CXCR5 is governed by a multifaceted transcriptional program regulating breast cancer progression. Biochim. Biophys. Acta Mol. Basis. Dis. 2019, 1865, 502-511. [CrossRef]

136. Mitkin, N.A.; Hook, C.D.; Schwartz, A.M.; Biswas, S.; Kochetkov, D.V.; Muratova, A.M.; Afanasyeva, M.A.; Kravchenko, J.E.; Bhattacharyya, A.; Kuprash, D.V. p53-dependent expression of CXCR5 chemokine receptor in MCF-7 breast cancer cells. Sci. Rep. 2015, 5, 9330. [CrossRef] [PubMed]

137. Geil, W.M.; Yen, A. Nuclear Raf-1 kinase regulates the CXCR5 promoter by associating with NFATc3 to drive retinoic acid-induced leukemic cell differentiation. FEBS J. 2014, 281, 1170-1180. [CrossRef]

138. Benard, J.; Douc-Rasy, S.; Ahomadegbe, J.C. TP53 family members and human cancers. Hum. Mutat. 2003, 21, 182-191. [CrossRef]

139. Mitkin, N.A.; Muratova, A.M.; Sharonov, G.V.; Korneev, K.V.; Sviriaeva, E.N.; Mazurov, D.; Schwartz, A.M.; Kuprash, D.V. p63 and 73 repress CXCR5 chemokine receptor gene expression in p53-deficient MCF-7 breast cancer cells during genotoxic stress. Biochim. Biophys. Acta Gene Regul. Mech. 2017, 1860, 1169-1178. [CrossRef]

140. Fan, L.; Zhu, Q.; Liu, L.; Zhu, C.; Huang, H.; Lu, S.; Liu, P. CXCL13 is androgen-responsive and involved in androgen induced prostate cancer cell migration and invasion. Oncotarget 2017, 8, 53244-53261. [CrossRef] [PubMed]

141. Petitprez, F.; de Reynies, A.; Keung, E.Z.; Chen, T.W.; Sun, C.M.; Calderaro, J.; Jeng, Y.M.; Hsiao, L.P.; Lacroix, L.; Bougouin, A.; et al. B cells are associated with survival and immunotherapy response in sarcoma. Nature 2020, 577, 556-560. [CrossRef]

142. Burger, J.A.; Gribben, J.G. The microenvironment in chronic lymphocytic leukemia (CLL) and other B cell malignancies: Insight into disease biology and new targeted therapies. Semin. Cancer Biol. 2014, 24, 71-81. [CrossRef] [PubMed]

143. Burkle, A.; Niedermeier, M.; Schmitt-Graff, A.; Wierda, W.G.; Keating, M.J.; Burger, J.A. Overexpression of the CXCR5 chemokine receptor, and its ligand, CXCL13 in B-cell chronic lymphocytic leukemia. Blood 2007, 110, 3316-3325. [CrossRef]

144. Ngo, V.N.; Korner, H.; Gunn, M.D.; Schmidt, K.N.; Riminton, D.S.; Cooper, M.D.; Browning, J.L.; Sedgwick, J.D.; Cyster, J.G. Lymphotoxin alpha/beta and tumor necrosis factor are required for stromal cell expression of homing chemokines in $\mathrm{B}$ and $\mathrm{T}$ cell areas of the spleen. J. Exp. Med. 1999, 189, 403-412. [CrossRef]

145. Swerdlow, S.H.; Campo, E.; Pileri, S.A.; Harris, N.L.; Stein, H.; Siebert, R.; Advani, R.; Ghielmini, M.; Salles, G.A.; Zelenetz, A.D.; et al. The 2016 revision of the World Health Organization classification of lymphoid neoplasms. Blood 2016, 127, 2375-2390. [CrossRef]

146. Hennessy, B.T.; Hanrahan, E.O.; Daly, P.A. Non-Hodgkin lymphoma: An update. Lancet Oncol. 2004, 5, 341-353. [CrossRef]

147. Stache, V.; Verlaat, L.; Gatjen, M.; Heinig, K.; Westermann, J.; Rehm, A.; Hopken, U.E. The splenic marginal zone shapes the phenotype of leukemia B cells and facilitates their niche-specific retention and survival. Oncoimmunology 2017, 6, e1323155. [CrossRef]

148. Caligaris-Cappio, F.; Bertilaccio, M.T.; Scielzo, C. How the microenvironment wires the natural history of chronic lymphocytic leukemia. Semin. Cancer Biol. 2014, 24, 43-48. [CrossRef] [PubMed]

149. Husson, H.; Freedman, A.S.; Cardoso, A.A.; Schultze, J.; Munoz, O.; Strola, G.; Kutok, J.; Carideo, E.G.; De Beaumont, R.; Caligaris-Cappio, F.; et al. CXCL13 (BCA-1) is produced by follicular lymphoma cells: Role in the accumulation of malignant B cells. Br. J. Haematol. 2002, 119, 492-495. [CrossRef]

150. Purdue, M.P.; Hofmann, J.N.; Kemp, T.J.; Chaturvedi, A.K.; Lan, Q.; Park, J.H.; Pfeiffer, R.M.; Hildesheim, A.; Pinto, L.A.; Rothman, N. A prospective study of 67 serum immune and inflammation markers and risk of non-Hodgkin lymphoma. Blood 2013, 122, 951-957. [CrossRef] [PubMed]

151. Hussain, S.K.; Zhu, W.; Chang, S.C.; Breen, E.C.; Vendrame, E.; Magpantay, L.; Widney, D.; Conn, D.; Sehl, M.; Jacobson, L.P.; et al. Serum levels of the chemokine CXCL13, genetic variation in CXCL13 and its receptor CXCR5, and HIV-associated non-hodgkin B-cell lymphoma risk. Cancer Epidemiol. Biomark. Prev. 2013, 22, 295-307. [CrossRef]

152. Widney, D.P.; Gui, D.; Popoviciu, L.M.; Said, J.W.; Breen, E.C.; Huang, X.; Kitchen, C.M.; Alcantar, J.M.; Smith, J.B.; Detels, R.; et al. Expression and Function of the Chemokine, CXCL13, and Its Receptor, CXCR5, in Aids-Associated Non-Hodgkin's Lymphoma. AIDS Res. Treat. 2010, 2010, 164586. [CrossRef] [PubMed]

153. Widney, D.P.; Gui, D.; Said, J.W.; Breen, E.C.; Detels, R.; Martinez-Maza, O. Expression and function of the chemokine, CXCL13, and its receptor, CXCR5, in AIDS-associated non-Hodgkin's lymphoma. Infect. Agents Cancer 2009, 4, S2. [CrossRef]

154. Trentin, L.; Cabrelle, A.; Facco, M.; Carollo, D.; Miorin, M.; Tosoni, A.; Pizzo, P.; Binotto, G.; Nicolardi, L.; Zambello, R.; et al. Homeostatic chemokines drive migration of malignant B cells in patients with non-Hodgkin lymphomas. Blood 2004, 104, 502-508. [CrossRef] [PubMed]

155. Kurtova, A.V.; Tamayo, A.T.; Ford, R.J.; Burger, J.A. Mantle cell lymphoma cells express high levels of CXCR4, CXCR5, and VLA-4 (CD49d): Importance for interactions with the stromal microenvironment and specific targeting. Blood 2009, 113, 4604-4613. [CrossRef] [PubMed]

156. Charbonneau, B.; Wang, A.H.; Maurer, M.J.; Asmann, Y.W.; Zent, C.S.; Link, B.K.; Ansell, S.M.; Weiner, G.J.; Ozsan, N.; Feldman, A.L.; et al. CXCR5 polymorphisms in non-Hodgkin lymphoma risk and prognosis. Cancer Immunol. Immunother. 2013, 62, 1475-1484. [CrossRef]

157. Chan, C.-C.; Shen, D.; Hackett, J.J.; Buggage, R.R.; Tuaillon, N. Expression of chemokine receptors, CXCR4 and CXCR5, and chemokines, BLC and SDF-1, in the eyes of patients with primary intraocular lymphoma. Ophthalmology 2003, 110, 421-426. [CrossRef] 
158. Rubenstein, J.L.; Wong, V.S.; Kadoch, C.; Gao, H.X.; Barajas, R.; Chen, L.; Josephson, S.A.; Scott, B.; Douglas, V.; Maiti, M.; et al. CXCL13 plus interleukin 10 is highly specific for the diagnosis of CNS lymphoma. Blood 2013, 121, 4740-4748. [CrossRef]

159. Brunn, A.; Montesinos-Rongen, M.; Strack, A.; Reifenberger, G.; Mawrin, C.; Schaller, C.; Deckert, M. Expression pattern and cellular sources of chemokines in primary central nervous system lymphoma. Acta Neuropathol. 2007, 114, 271-276. [CrossRef]

160. Smith, J.R.; Braziel, R.M.; Paoletti, S.; Lipp, M.; Uguccioni, M.; Rosenbaum, J.T. Expression of B-cell-attracting chemokine 1 (CXCL13) by malignant lymphocytes and vascular endothelium in primary central nervous system lymphoma. Blood 2003, 101, 815-821. [CrossRef]

161. Kim, S.J.; Ryu, K.J.; Hong, M.; Ko, Y.H.; Kim, W.S. The serum CXCL13 level is associated with the Glasgow Prognostic Score in extranodal NK/T-cell lymphoma patients. J. Hematol. Oncol. 2015, 8, 49. [CrossRef] [PubMed]

162. Bass, A.J.; Watanabe, H.; Mermel, C.H.; Yu, S.; Perner, S.; Verhaak, R.G.; Kim, S.Y.; Wardwell, L.; Tamayo, P.; Gat-Viks, I.; et al. SOX2 is an amplified lineage-survival oncogene in lung and esophageal squamous cell carcinomas. Nat. Genet. 2009, 41, 1238-1242. [CrossRef] [PubMed]

163. Dupuis, J.; Boye, K.; Martin, N.; Copie-Bergman, C.; Plonquet, A.; Fabiani, B.; Baglin, A.C.; Haioun, C.; Delfau-Larue, M.H.; Gaulard, P. Expression of CXCL13 by neoplastic cells in angioimmunoblastic T-cell lymphoma (AITL): A new diagnostic marker providing evidence that AITL derives from follicular helper T cells. Am. J. Surg. Pathol. 2006, 30, 490-494. [CrossRef]

164. Ohmatsu, H.; Sugaya, M.; Kadono, T.; Tamaki, K. CXCL13 and CCL21 are expressed in ectopic lymphoid follicles in cutaneous lymphoproliferative disorders. J. Investig. Dermatol. 2007, 127, 2466-2468. [CrossRef]

165. Mori, M.; Manuelli, C.; Pimpinelli, N.; Bianchi, B.; Orlando, C.; Mavilia, C.; Cappugi, P.; Maggi, E.; Giannotti, B.; Santucci, M. BCA-1, A B-cell chemoattractant signal, is constantly expressed in cutaneous lymphoproliferative B-cell disorders. Eur. J. Cancer 2003, 39, 1625-1631. [CrossRef]

166. O'Callaghan, D.S.; O'Donnell, D.; O'Connell, F.; O'Byrne, K.J. The Role of Inflammation in the Pathogenesis of Non-small Cell Lung Cancer. J. Thorac. Oncol. 2010, 5, 2024-2036. [CrossRef] [PubMed]

167. Eide, H.A.; Halvorsen, A.R.; Sandhu, V.; Fane, A.; Berg, J.; Haakensen, V.D.; Kure, E.H.; Brustugun, O.T.; Kiserud, C.E.; Kyte, J.A.; et al. Non-small cell lung cancer is characterised by a distinct inflammatory signature in serum compared with chronic obstructive pulmonary disease. Clin. Transl. Immunol. 2016, 5, e109. [CrossRef]

168. Zhang, Y.; Yu, K.; Hu, S.; Lou, Y.; Liu, C.; Xu, J.; Li, R.; Zhang, X.; Wang, H.; Han, B. MDC and BLC are independently associated with the significant risk of early stage lung adenocarcinoma. Oncotarget 2016, 7, 83051-83059. [CrossRef] [PubMed]

169. Singh, R.; Gupta, P.; Kloecker, G.H.; Singh, S.; Lillard, J.W., Jr. Expression and clinical significance of CXCR5/CXCL13 in human nonsmall cell lung carcinoma. Int. J. Oncol. 2014, 45, 2232-2240. [CrossRef] [PubMed]

170. Vachani, A.; Nebozhyn, M.; Singhal, S.; Alila, L.; Wakeam, E.; Muschel, R.; Powell, C.A.; Gaffney, P.; Singh, B.; Brose, M.S.; et al. A 10-gene classifier for distinguishing head and neck squamous cell carcinoma and lung squamous cell carcinoma. Clin. Cancer Res. 2007, 13, 2905-2915. [CrossRef] [PubMed]

171. de Chaisemartin, L.; Goc, J.; Damotte, D.; Validire, P.; Magdeleinat, P.; Alifano, M.; Cremer, I.; Fridman, W.H.; Sautes-Fridman, C.; Dieu-Nosjean, M.C. Characterization of chemokines and adhesion molecules associated with T cell presence in tertiary lymphoid structures in human lung cancer. Cancer Res. 2011, 71, 6391-6399. [CrossRef]

172. Siegel, R.L.; Miller, K.D.; Jemal, A. Cancer statistics, 2019. CA Cancer J. Clin. 2019, 69, 7-34. [CrossRef]

173. Singh, S.; Singh, R.; Singh, U.P.; Rai, S.N.; Novakovic, K.R.; Chung, L.W.; Didier, P.J.; Grizzle, W.E.; Lillard, J.W., Jr. Clinical and biological significance of CXCR5 expressed by prostate cancer specimens and cell lines. Int. J. Cancer 2009, 125, 2288-2295. [CrossRef] [PubMed]

174. Seidenfeld, J.; Samson, D.J.; Hasselblad, V.; Aronson, N.; Albertsen, P.C.; Bennett, C.L.; Wilt, T.J. Single-therapy androgen suppression in men with advanced prostate cancer: A systematic review and meta-analysis. Ann. Intern. Med. 2000, 132, 566-577. [CrossRef] [PubMed]

175. Primo, N.; Lara, J.F.J.M. Treatment options for androgen-independent prostate cancer. Cancer Investig. 1999, 17, 137-144.

176. Gittes, R.F. Carcinoma of the prostate. N. Engl. J. Med. 1991, 324, 236-245. [CrossRef] [PubMed]

177. Ammirante, M.; Kuraishy, A.I.; Shalapour, S.; Strasner, A.; Ramirez-Sanchez, C.; Zhang, W.; Shabaik, A.; Karin, M. An IKKalphaE2F1-BMI1 cascade activated by infiltrating B cells controls prostate regeneration and tumor recurrence. Genes Dev. 2013, 27, 1435-1440. [CrossRef]

178. Bonizzi, G.; Bebien, M.; Otero, D.C.; Johnson-Vroom, K.E.; Cao, Y.; Vu, D.; Jegga, A.G.; Aronow, B.J.; Ghosh, G.; Rickert, R.C.; et al. Activation of IKKalpha target genes depends on recognition of specific kappaB binding sites by RelB:p52 dimers. EMBO J. 2004, 23, 4202-4210. [CrossRef]

179. Kortylewski, M.; Yu, H. Stat3 as a potential target for cancer immunotherapy. J. Immunother. 2007, 30, 131-139. [CrossRef] [PubMed]

180. Chen, L.; Huang, Z.; Yao, G.; Lyu, X.; Li, J.; Hu, X.; Cai, Y.; Li, W.; Li, X.; Ye, C. The expression of CXCL13 and its relation to unfavorable clinical characteristics in young breast cancer. J. Transl. Med. 2015, 13, 168. [CrossRef]

181. Panse, J.; Friedrichs, K.; Marx, A.; Hildebrandt, Y.; Luetkens, T.; Barrels, K.; Horn, C.; Stahl, T.; Cao, Y.; Milde-Langosch, K.; et al. Chemokine CXCL13 is overexpressed in the tumour tissue and in the peripheral blood of breast cancer patients. Br. J. Cancer 2008, 99, 930-938. [CrossRef] 
182. Razis, E.; Kalogeras, K.T.; Kotoula, V.; Eleftheraki, A.G.; Nikitas, N.; Kronenwett, R.; Timotheadou, E.; Christodoulou, C.; Pectasides, D.; Gogas, H.; et al. Improved outcome of high-risk early HER2 positive breast cancer with high CXCL13-CXCR5 messenger RNA expression. Clin. Breast Cancer 2012, 12, 183-193. [CrossRef]

183. Zhang, Z.; Zhu, Y.; Wang, Z.; Zhang, T.; Wu, P.; Huang, J. Yin-yang effect of tumor infiltrating B cells in breast cancer: From mechanism to immunotherapy. Cancer Lett. 2017, 393, 1-7. [CrossRef]

184. Gu-Trantien, C.; Loi, S.; Garaud, S.; Equeter, C.; Libin, M.; de Wind, A.; Ravoet, M.; Le Buanec, H.; Sibille, C.; Manfouo-Foutsop, G.; et al. CD4(+) follicular helper T cell infiltration predicts breast cancer survival. J. Clin. Investig. 2013, 123, 2873-2892. [CrossRef]

185. Razmkhah, M.; Jaberipour, M.; Safaei, A.; Talei, A.R.; Erfani, N.; Ghaderi, A. Chemokine and chemokine receptors: A comparative study between metastatic and nonmetastatic lymph nodes in breast cancer patients. Eur. Cytokine Netw. 2012, 23, 72-77. [CrossRef]

186. Curtaz, C.J.; Schmitt, C.; Herbert, S.L.; Feldheim, J.; Schlegel, N.; Gosselet, F.; Hagemann, C.; Roewer, N.; Meybohm, P.; Wockel, A.; et al. Serum-derived factors of breast cancer patients with brain metastases alter permeability of a human blood-brain barrier model. Fluids Barriers CNS 2020, 17, 31. [CrossRef]

187. Qi, X.-W.; Xia, S.-H.; Yin, Y.; Jin, L.-F.; Pu, Y.; Hua, D.; Wu, H.-R. Expression features of CXCR5 and its ligand, CXCL13 associated with poor prognosis of advanced colorectal cancer. Eur. Rev. Med. Pharmacol. Sci. 2014, 18, 1916-1924. [PubMed]

188. Obermeier, F.; Schwarz, H.; Dunger, N.; Strauch, U.G.; Grunwald, N.; Scholmerich, J.; Falk, W. OX40/OX40L interaction induces the expression of CXCR5 and contributes to chronic colitis induced by dextran sulfate sodium in mice. Eur. J. Immunol 2003, 33, 3265-3274. [CrossRef] [PubMed]

189. Pandruvada, S.N.M.; Yuvaraj, S.; Liu, X.; Sundaram, K.; Shanmugarajan, S.; Ries, W.L.; Norris, J.S.; London, S.D.; Reddy, S.V. Role of CXC chemokine ligand 13 in oral squamous cell carcinoma associated osteolysis in athymic mice. Int. J. Cancer 2010, 126, 2319-2329. [CrossRef] [PubMed]

190. Li, K.; Guo, Q.; Zhang, X.; Dong, X.; Liu, W.; Zhang, A.; Li, Y.; Yan, J.; Jia, G.; Zheng, Z.; et al. Oral cancer-associated tertiary lymphoid structures: Gene expression profile and prognostic value. Clin. Exp. Immunol. 2020, 199, 172-181. [CrossRef]

191. Xuyan Chen, R.C. Ruifang Jin, Zhiming Huang, The role of CXCL chemokine family in the development and progression of gastric cancer. Int. J. Clin. Exp. Pathol. 2020, 13, 484-492.

192. Wei, Y.; Lin, C.; Li, H.; Xu, Z.; Wang, J.; Li, R.; Liu, H.; Zhang, H.; He, H.; Xu, J. CXCL13 expression is prognostic and predictive for postoperative adjuvant chemotherapy benefit in patients with gastric cancer. Cancer Immunol. Immunother. 2017, 67, 261-269. [CrossRef] [PubMed]

193. Hofman, V.J.; Moreilhon, C.; Brest, P.D.; Lassalle, S.; Le Brigand, K.; Sicard, D.; Raymond, J.; Lamarque, D.; Hébuterne, X.A.; Mari, B.; et al. Gene expression profiling in human gastric mucosa infected with Helicobacter pylori. Mod. Pathol. 2007, 20, 974-989. [CrossRef]

194. Li, C.; Kang, D.; Sun, X.; Liu, Y.; Wang, J.; Gao, P. The Effect of C-X-C Motif Chemokine 13 on Hepatocellular Carcinoma Associates with Wnt Signaling. Biomed. Res. Int. 2015, 2015, 345413. [CrossRef] [PubMed]

195. Li, Y.; Tang, L.; Guo, L.; Chen, C.; Gu, S.; Zhou, Y.; Ye, G.; Li, X.; Wang, W.; Liao, X.; et al. CXCL13-mediated recruitment of intrahepatic CXCR5(+)CD8(+) T cells favors viral control in chronic HBV infection. J. Hepatol. 2020, 72, 420-430. [CrossRef] [PubMed]

196. Schafer, P.H.; Kivitz, A.J.; Ma, J.; Korish, S.; Sutherland, D.; Li, L.; Azaryan, A.; Kosek, J.; Adams, M.; Capone, L.; et al. Spebrutinib (CC-292) Affects Markers of B Cell Activation, Chemotaxis, and Osteoclasts in Patients with Rheumatoid Arthritis: Results from a Mechanistic Study. Rheumatol. Ther. 2019, 7, 101-119. [CrossRef] [PubMed]

197. Helmink, B.A.; Reddy, S.M.; Gao, J.; Zhang, S.; Basar, R.; Thakur, R.; Yizhak, K.; Sade-Feldman, M.; Blando, J.; Han, G.; et al. B cells and tertiary lymphoid structures promote immunotherapy response. Nature 2020, 577, 549-555. [CrossRef] [PubMed]

198. Zhang, Y.; Chen, H.; Mo, H.; Hu, X.; Gao, R.; Zhao, Y.; Liu, B.; Niu, L.; Sun, X.; Yu, X.; et al. Single-cell analyses reveal key immune cell subsets associated with response to PD-L1 blockade in triple-negative breast cancer. Cancer Cell 2021. [CrossRef] [PubMed] 